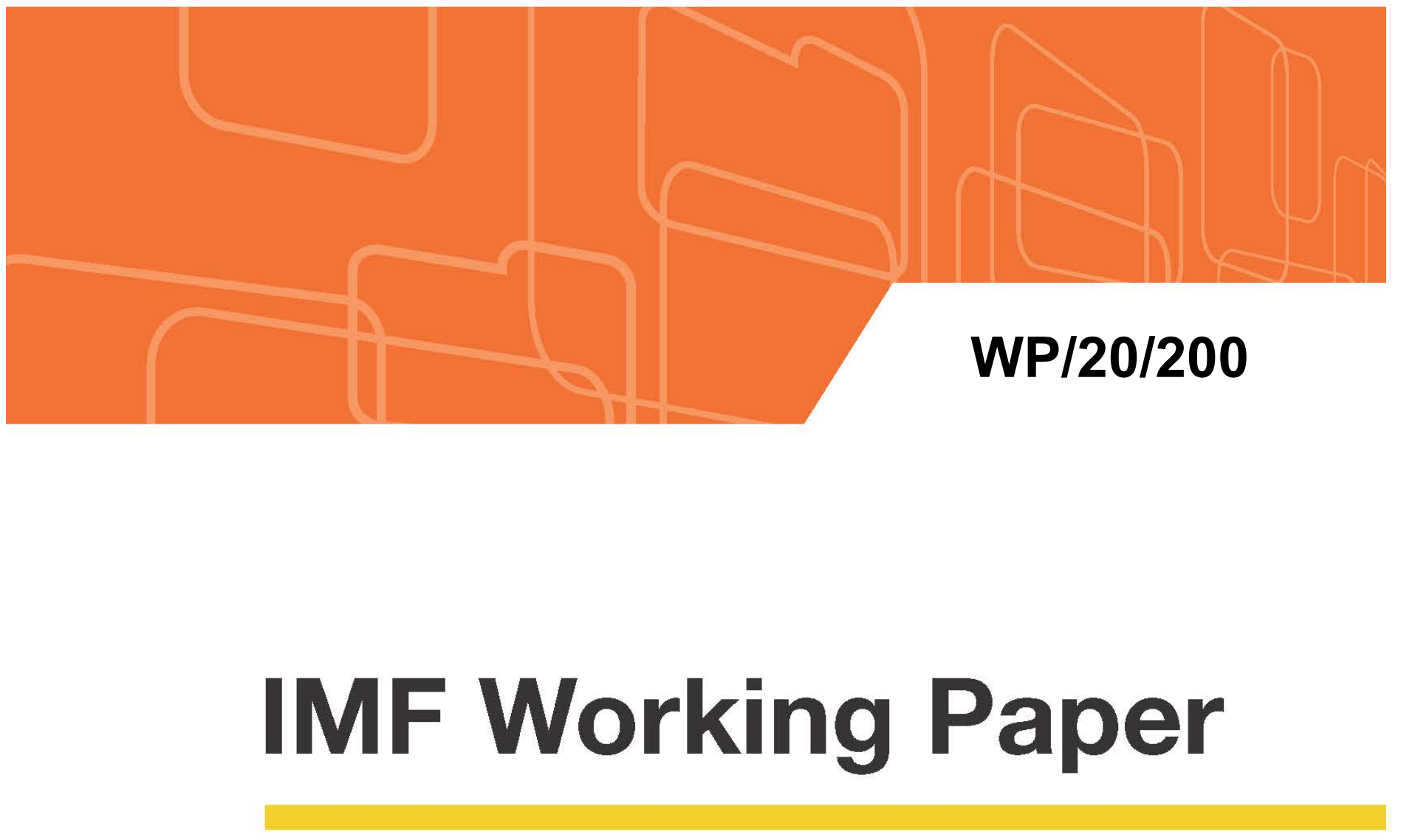

\title{
Demographics and the Housing Market: Japan's Disappearing
} Cities

by Yuko Hashimoto, Gee Hee Hong, and Xiaoxiao Zhang

IMF Working Papers describe research in progress by the author(s) and are published to elicit comments and to encourage debate. The views expressed in IMF Working Papers are those of the author(s) and do not necessarily represent the views of the IMF, its Executive Board, or IMF management.

$$
\text { I N T E R N A T I O N A L M O N E T A R Y F U N D }
$$




\title{
IMF Working Paper
}

\author{
Asia Pacific Department
}

\section{Demographics and the Housing Market: Japan's Disappearing Cities}

\section{Prepared by Yuko Hashimoto, Gee Hee Hong, and Xiaoxiao Zhang1}

Authorized for distribution by Paul Cashin

September 2020

IMF Working Papers describe research in progress by the author(s) and are published to elicit comments and to encourage debate. The views expressed in IMF Working Papers are those of the author(s) and do not necessarily represent the views of the IMF, its Executive Board, or IMF management.

\begin{abstract}
How does a shrinking population affect the housing market? In this study, drawing on Japan's experience, we find that there exists an asymmetric relationship between housing prices and population change. Due to the durability of housing structures, the decline in housing prices associated with population losses is estimated to be larger than the rise in prices associated with population increases. Given that population losses have been and are projected to be more acute in rural areas than urban areas in Japan, the on-going demographic transition in Japan could worsen regional disparities, as falling house prices in rural areas could intensify population outflows. Policy measures to promote more even population growth across regions, and avoid the over-supply of houses, are critical to stabilize house prices with a shrinking population.
\end{abstract}

JEL Classification Numbers: C33, J11, R31, R38

Keywords: population change, house prices, durable housing model, akiya (vacant houses), regional disparity

Authors' E-Mail Addresses: yhashimoto@imf.org; ghong@imf.org; xz413@,cam.ac.uk

\footnotetext{
${ }^{1}$ We would like to thank Helge Berger, Paul Cashin, Giovanni Dell'Ariccia, Kenneth Kang, Gaston Gelos, Gita Gopinath, Gian Maria Milesi-Ferretti, Takuji Tanaka, Ken Chikada, and seminar participants at the Bank of Japan (during the 2019 Japan Article IV mission), the IMF Surveillance Meeting, the IMF Asia and Pacific Department Discussion Forum, and the RESSI-MF seminar, for helpful comments and suggestions. The work commenced when Zhang was a research assistant in the IMF Research Department.
} 
Table of Contents

Abstract ___ 1

I. Introduction

II. Demographic Trends in Japan ___ 6

A. Population Change at Prefecture Level

B. Japanese Households: Total Number and Composition

III. Housing Price Developments in Japan ___ 11

A. House Price Changes Across Prefectures

B. House Price Changes by Housing Type

C. Tokyo Story __ 14

IV. Modeling Population Growth and Housing Prices ___ 17

A. Theoretical Framework

B. Empirical Analysis __ 18

V. Policy Implications __ 20

A. Why Move to Large Cities? 21

B. Human Capital and Housing Price Changes __ 22

B. Implications for Household Balance Sheets 22

C. Overinvestment and Housing Market Policy __ 24

VI. Conclusion _ 25

References __ 27

Figures

1. Japan's Population and its Age-group Composition

2. Kernel Density of Population Growth by Prefecture

3. Changes in Rate of Net-Migration in Four Major Metropolitan Areas ___ 8

4. Changes in Change in Prefecture-Level Concentration: 1996-2015 __ 8

5. Households and Family Members

6. Residential Land Price Trend in Japan __ 11

7. Housing Price Change Over Time by Prefecture (in percent) __ 12

8. Housing Price Movements by Property Types __ 13

9. Institutional Investment in J-REIT __ 14

10. Supply and Demand in Tokyo Housing Market 15

11. Tokyo Metropolitan Area: New Condominium Supply and Prices _ 16

12. Nonlinear Relationship between Population Growth and House Price Changes __ 18

13. Changes in House Price and Net Migration Flows (1996-2018) __ 19

14. Education and House Prices __ 22

15. Change in Household Balance Sheet Values 1994-2017 (Trillion Yen) ___ 23 
Tables

1. Speed of Population Change

2. House Price Changes and Population Change

Annexes

A. Household Numbers and the Housing Market

B. Development of Housing Market in Japan from 1982 to 2012

C. Japan Tax Policies Related to the Housing Market 


\section{INTRODUCTION}

Advanced economies are in the middle of a significant demographic transition. Population growth is slowing, due to a combination of low fertility and an increased life expectancy (OECD, 2019; United Nations, 2017). A shrinking population poses significant economic challenges, as studies find that the loss of workers could lead to lower productivity growth, lower potential growth and a steady rise in age-related fiscal costs such as pensions and medical care (IMF 2018, 2020; McGrattan et al. 2018; Westelius and Liu, 2016; Colacelli and Fernandez-Corugedo, 2018).

Japan is a country at the leading edge of this demographic change, as total population growth has turned negative since 2011 (Figure 1). ${ }^{2}$ Another dimension of Japan's demographic challenge is its aging population. The old age dependency ratio (measured as a share of the old-age population over the working-age population) has been on the rise: the ratio exceeded 40 percent in 2014 and is expected to accelerate, reaching above 70 percent in the next 50 years (IMF 2017; Shirakawa 2012).

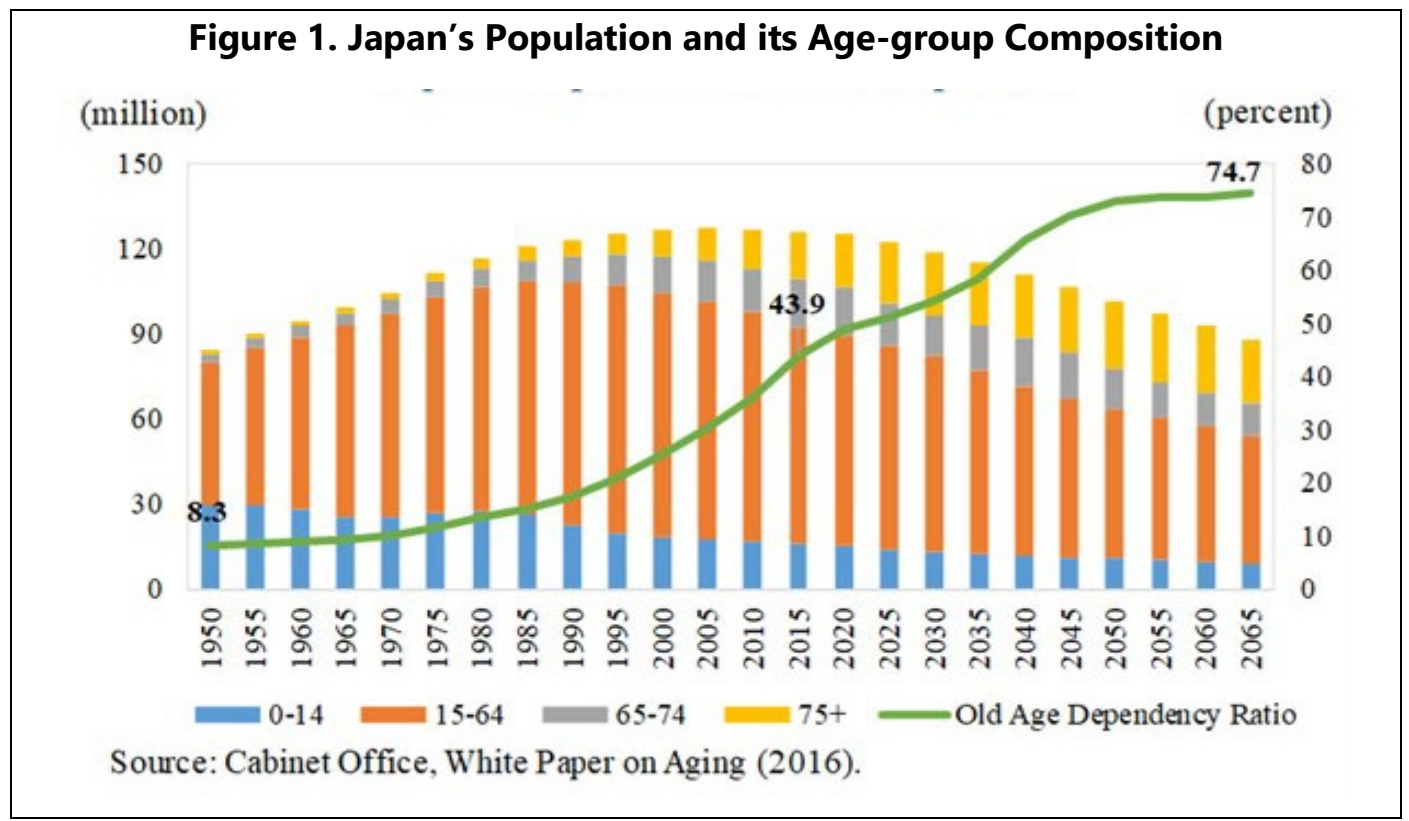

Interestingly, how the demographic transition has unfolded varies greatly across regions in Japan. Population is declining in most prefectures due to low fertility rate and outbound migration to large cities, while population is growing in key major cities with inbound migration, contributing to an increase in population concentration in large cities. As a result, Japan will likely become a highly polarized country in terms of population concentration. At the same time, the on-going population dynamics have affected the housing supply and demand dynamics differentially across regions. For instance, the declining population in rural areas has

\footnotetext{
${ }^{2}$ Source: National Institute of Population and Social Security Research, based on the medium-variant fertility and medium-variant mortality projection. http://www.ipss.go.jp/pp-newest/e/ppfj02/suikei_g_e.html
} 
generated empty houses (akiya) across the country, particularly in rural areas, which, by some estimates, will rise to comprise as much as one third of total houses by 2033.

Against this backdrop, in this paper we focus on the regional differences in population dynamics and analyze how demographic changes have influenced house prices in Japan. Using the data on residential land price as a proxy for house prices and population by prefectures (our unit of a 'region') from 1975, we address the following four questions:

- What has been the pattern of prefecture-level population dynamics in Japan in the last forty years?

- During this time, how have residential house prices evolved over time in Japan and by prefecture?

- How important is the demographic factor as a driver of house price dynamics in Japan? Has the relationship between demographics and house prices evolved over time?

- What are the potential policy implications?

First, we observe a stark difference in the demographic transition between urban areas and rural areas during this period. As early as the 1990s, a number of prefectures in rural areas have demonstrated negative population growth. Over time, more prefectures joined the list. For instance, in 1998, there were thirty-four prefectures (out of a total of forty-seven prefectures) with negative population growth. Twenty years later, in 2017 , the list had expanded to forty prefectures. Seven prefectures that recorded positive population growth in 2017 are large cities, four of which cover the Tokyo Metropolitan area-Tokyo-to, Saitama, Chiba and Kanagawa prefectures. Three other prefectures with positive population growth are other major cities like Osaka, Fukuoka and Nagoya. In sum, over time, Japan's population density has become polarized with higher concentration in urban areas.

Second, we observe that residential house prices in Japan declined steadily after the bubble burst in the early 1990s. Since 2013, the downward trend has reversed with the advent of Abenomics, as house prices stabilized, either with a mild increase in some prefectures or no change in house prices in others. In fact, in some large cities and tourist destinations, a sharp appreciation of condominium prices has even been observed.

Third, we find that there exists a positive correlation between population growth and house prices - a 1 percent increase in population growth is associated with a 5 percentage points increase in house prices. Furthermore, we find that this positive correlation embeds a nonlinear relationship between population growth and house price changes. Consistent with the durable housing model (Glaeser and Gyourko (2005)), the magnitude of house price decreases associated with population decline is larger than the magnitude of house price increases associated with population increase of the same magnitude in absolute terms. ${ }^{3}$ This non-linear

\footnotetext{
${ }^{3}$ The key intuition of Glaeser and Gyourko (2005) is that houses can be built quickly with increasing demand, while they cannot disappear as fast with decreasing demand. This is because houses are quintessential durable goods, implying that housing supply is elastic when the demand increases, but housing supply is inelastic with
}

(continued...) 
relationship is time-varying. Using the same data looking at just the last ten years, the positive correlation between an increase in population and an increase in house prices has weakened, although the positive correlation between negative population growth and the decline in house prices remains.

Finally, our policy implications highlight the importance of policies to promote more even growth across regions. For rural areas, this involves attracting and maintaining workers and preventing over-supply of houses with declining populations. Rural prefectures that are not able to attract people will face several economic challenges. If the so-called 'brain drain' intensifies in rural areas, population outflows will negatively affect productivity and economic growth of regions, as high-skilled workers, the more mobile ones with attractive opportunities outside of the region, are likely to leave. At the same time, if housing supply does not properly adjust to declining population and over-supply is generated, downward pressures on house prices will amplify the negative feedback loop between population growth and house prices. Financial stability concerns could arise with deterioration of household and regional bank balance sheets. On the other hand, prefectures with the risk of higher population concentration need to have appropriate policies to address the distributional issues within the prefecture, particularly those related to urban poverty.

The rest of the paper is organized as follows. Section II discusses Japan's demographic trends, highlighting significant regional differences. Section III discusses the development of housing prices in Japan, while zeroing in on the Greater Tokyo-area. In Section IV, we analyze the empirical relationship between population changes and housing price changes. Section V discusses policy implications and Section VI concludes.

\section{DEMOgRAPHIC TRENDS IN JAPAN}

\section{A. Population Change at Prefecture Level}

In this section, we document the patterns of population dynamics across prefectures in Japan since 1975. Figure 2 shows the distribution of prefecture-level population change in two periods: from 1975 to 1990 and from 1990 to 2015. The leftward shift of the distribution of prefecture-level population change over time suggests that a large number of prefectures that exhibited population growth before 1990 experienced population decline since 1990.

Between 1975 and 1990, every prefecture in Japan except for two prefectures (Akita and Nagasaki) experienced positive population growth, albeit at a different pace, shown by the large dispersion of the distribution. During this period, the average population growth across regions registered around 9 percent, with the median of 6.7 percent. However, starting from 1990 , the number of prefectures with population declines rose sharply, as thirty prefectures out of forty-seven experienced population declines. Prefectures that experienced the largest decline in population are concentrated in Tohoku, Shikoku and Kyushu regions. For instance, in 1998, there are thirteen prefectures with net positive population growth.

declining population. This generates a kinked supply curve which is highly elastic when prices are at or above construction costs and highly inelastic otherwise. 
Figure 2. Kernel Density of Population Growth by Prefecture

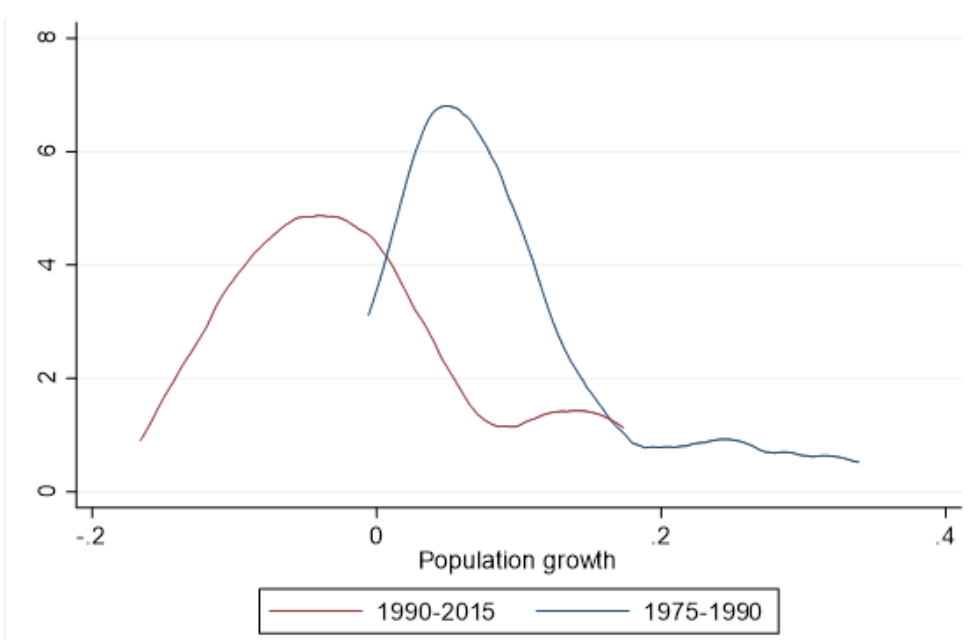

Source: Statistics Bureau, Japan and authors' calculation.

The change in population dynamics - especially in areas that experienced a large decline in population - cannot be explained solely by the natural population change (the numbers of births and deaths). ${ }^{4}$ Cross-prefecture net migrations, defined as population migration inflows minus migration outflows, are important drivers of Japan's prefecture-level population dynamics. ${ }^{5}$ Figure 3 depicts the rate of net migration into four major metropolitan areas since 1971, where the four metropolitan areas are defined as Tokyo, Osaka, Nagoya and Fukuoka. Until 2007, all four regions showed positive change in net migration rate, implying that the speed of inflows outpaced the speed of outflows. The mirror image of this trend is the negative change of rate observed for the rest of Japan (in green) since the late 1990s. Since 2007, only Tokyo-to (dotted orange line) and the Greater Tokyo Metropolitan area (solid orange line) continue to show positive growth and the rate even picked up since 2012.

\footnotetext{
${ }^{4}$ According to Population Statistics Year 2019 (National Institute of Population and Social Security Research, Japan), the number of births continued declining since 1973 (the peak was 2,091,983 in 1973), and it fell below the number of deaths for the first time in around 2005. The births and deaths numbers in FY2017 were 946,065 and $1,340,397$, respectively.

${ }^{5}$ In fact, internal migration contributes to population changes largely. For example, population changes due to internal migration (outflows) accounted for half of population changes due to natural decrease in Tohoku area in 2017. In contrast, in prefectures such as Tokyo, Kanagawa, Chiba, Saitama, Aichi, and Fukuoka, percentage change of population due to the natural increase was negative (births were lower than deaths), but the percentage change of population due to net migration (inflows) was positive and exceeded the negative natural population change. (Population Statistics Year 2019 (National Institute of Population and Social Security Research, Japan)).
} 
Figure 3. Changes in Rate of Net-Migration in Four Major Metropolitan Areas

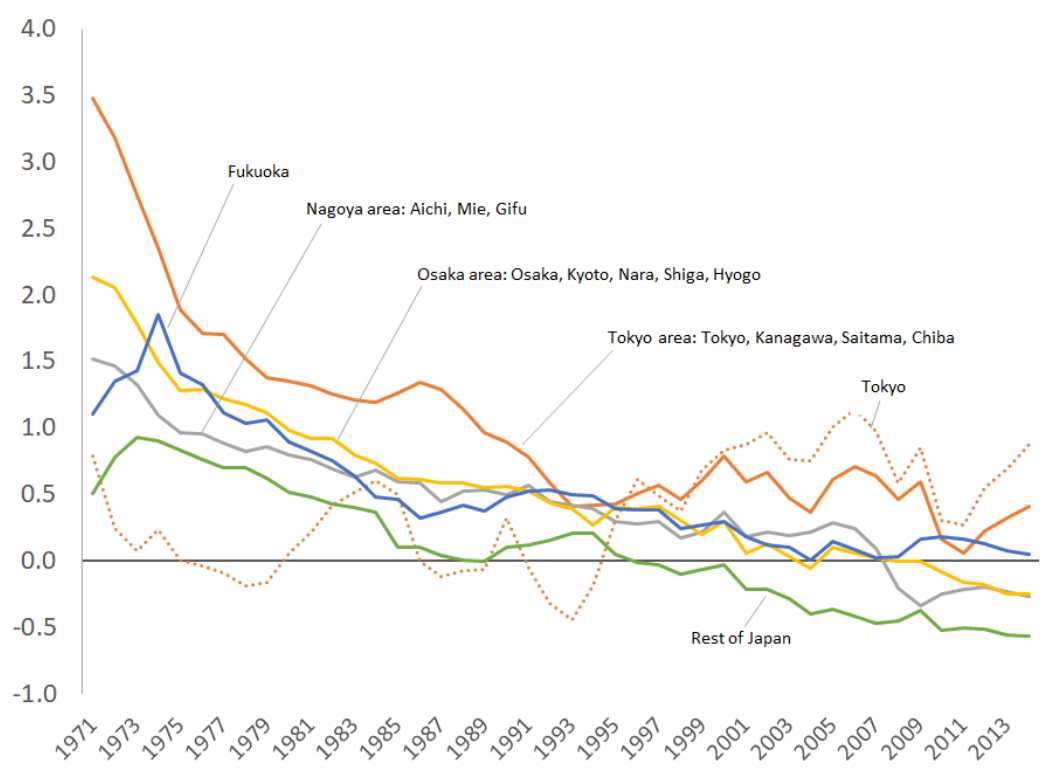

Source: Statistics Bureau, Japan and IMF staff calculations.

This implies the intensification of population concentration in major cities and a polarization of population density in Japan. Figure 4 shows the change in population concentration (and loss) for each prefecture over the past twenty years. The concentration in Tokyo increased by the largest amount (1.3 percent). On the other hand, other prefectures experienced a decline in population concentration, with the largest decline observed for Hokkaido ( -0.3 percent). Only six prefectures recorded an increase in population concentration-Tokyo, Kanagawa, Saitama, Hyogo, Shiga, and Fukuoka. These prefectures are either large cities or surrounding (residential) areas of large cities (for instance, Shiga and Hyogo prefectures close to Osaka).

Figure 4. Changes in Change in Prefecture-Level Concentration: 1996-2015

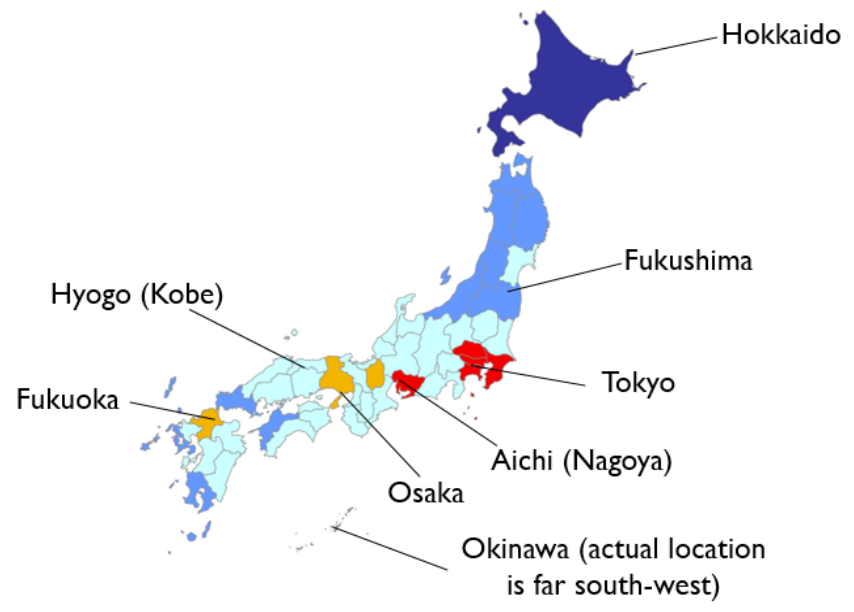

Source: Statistics Bureau, Japan and IMF staff calculations. 
We run the following regression, following Glaeser and Gyourko (2005), which suggests the direction of population change and the speed of population change:

$$
\text { population growth rate }(\%)_{i, t}=\alpha+\beta P O P L O S S_{i, t-1}+\gamma P O P G A I N_{i, t-1}+\varepsilon i t \text {, }
$$

where $i$ refers to prefecture and $t$ refers to year. POPLOSS variable takes on a value of zero if prefecture $i$ 's population grew during the period $t$ and equals prefecture's actual percentage decline in population if the prefecture lost population during the period. Similarly, POPGAIN variable takes on a value of zero if prefecture $i$ experienced population loss during the period of $t$, and equals the actual population growth rate if the prefecture gained population.

Results are shown in Table 1. Columns (1) to (5) show results using different sample periods. Columns (2) and (3) show the results using different samples before and after the asset bubble burst in 1990. Column (4) represents the period when Japan's total population increased, while column (5) represents the sample when Japan's total population began to decline.

Our results show a clear sign of polarization of population dynamics. The positive coefficients for both population gains and losses across columns confirms the acceleration of population inflows into already-concentrated prefectures and the population outflows from prefectures with negative population growth. The relationship has changed over time, and more asymmetry between population gain and population loss is observed for the most recent periods. During the period between 1975 and 1990, a 1 percent population loss in the previous year is associated with a 0.78 percent population decline in the current year, which is slightly larger than the impact of population gains of 0.71 percent (column (2)). However, the caveat is that most of the samples were experiencing positive population growth during this period. Columns (3) through (5) suggest that the coefficients of population gain is higher than those of population losses and such asymmetry is larger for the most recent periods: column (5), population gain is more persistent with the population gain in ensuing period (0.77), than population loss (0.17). This implies that concentration into prefectures with population gains is accelerating, while population loss in the rest of prefectures are more gradual.

\begin{tabular}{|c|c|c|c|c|c|}
\hline \multicolumn{6}{|c|}{ Table 1. Speed of Population Change } \\
\hline & \multicolumn{5}{|c|}{ Population growth (\%) } \\
\hline & (1) & (2) & (3) & (4) & (5) \\
\hline & $1975-2015$ & $1975-1990$ & $1990-2015$ & $1975-2011$ & 2011-2015 \\
\hline \multirow[t]{2}{*}{ POPLOSS $\mathrm{t}-1$} & $0.713^{* * *}$ & $0.778^{* * *}$ & $0.650^{* * *}$ & $0.706^{* * *}$ & $0.170^{* *}$ \\
\hline & $(0.0594)$ & $(0.0563)$ & $(0.0779)$ & $(0.0728)$ & $(0.0832)$ \\
\hline \multirow[t]{2}{*}{ POPGAIN t-1 } & $0.837^{* * *}$ & $0.714^{* * *}$ & $0.707^{* * *}$ & $0.840^{* * *}$ & $0.770^{* * *}$ \\
\hline & $(0.0357)$ & $(0.0346)$ & $(0.0716)$ & $(0.0330)$ & $(0.112)$ \\
\hline \multirow[t]{2}{*}{ Constant } & $0.000958^{* * *}$ & $0.00217^{* * *}$ & $0.000796^{* *}$ & $0.000921^{* * *}$ & $-0.00341^{* * *}$ \\
\hline & $(0.000343)$ & $(0.000358)$ & $(0.000370)$ & $(0.000321)$ & $(0.000351)$ \\
\hline Observations & 1,751 & 635 & 1,072 & 1,563 & 141 \\
\hline R-squared & 0.916 & 0.850 & 0.800 & 0.904 & 0.338 \\
\hline Number of code & 47 & 47 & 47 & 47 & 47 \\
\hline Fixed effects & $\mathrm{Y}$ & $\mathrm{Y}$ & $\mathrm{Y}$ & $\mathrm{Y}$ & $\mathrm{Y}$ \\
\hline Time effects & $\mathrm{Y}$ & $\mathrm{Y}$ & $\mathrm{Y}$ & Y & $\mathrm{Y}$ \\
\hline \multicolumn{6}{|c|}{ Robust standard errors in parentheses } \\
\hline \multicolumn{6}{|c|}{$* * * p<0.01, * * p<0.05, * p<0.1$} \\
\hline
\end{tabular}




\section{B. Japanese Households: Total Number and Composition}

In this section, we document how the total number and the composition of Japanese households has changed over time. Total population may not be a perfect proxy for housing demand, especially in cases of high population mobility. For instance, when many young people move to major cities for education and career opportunities, the number of households may be a better measure of housing demand, rather than the total population. ${ }^{6}$

Despite the declining population since 2011, the total number of households in Japan continued to increase until 2016 and has since stabilized at around 53 million households. According to the official projection by the National Institute of Population and Social Security Research of Japan, the number of households will reach its peak in 2023, at around 54.2 million, and start a gradual decline $\mathrm{n}$ to around 50.8 million households by 2040 , which is slightly below the total household numbers in 2010.

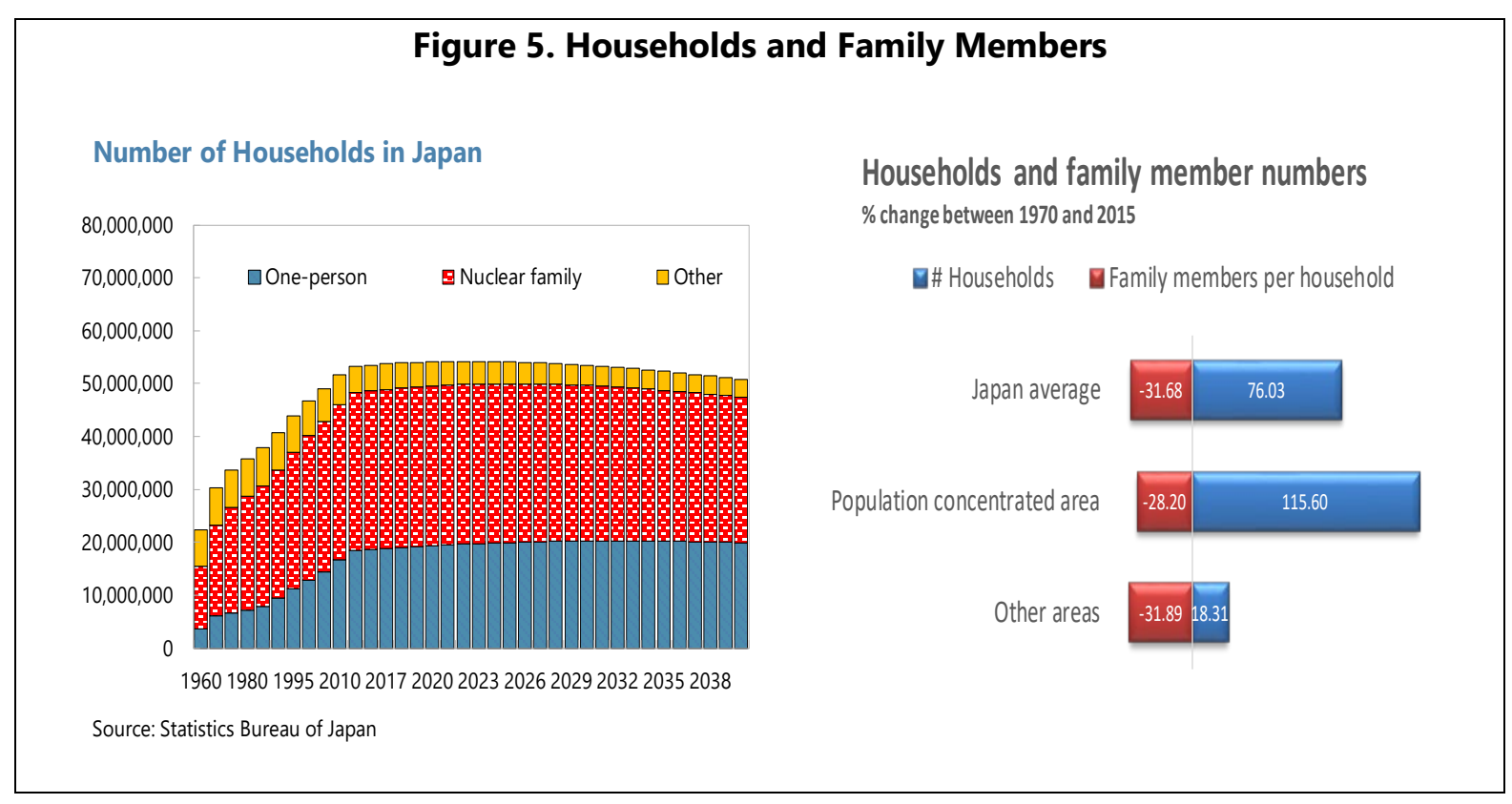

The increase of household numbers notwithstanding, the declining population reflects some important changes in the composition and the size of Japanese households. In the old days, a typical Japanese family would consist of "three-generation," (grandparents, parents, and children). Nowadays, a nuclear family consisting of two generations (parents and children) has become the standard household.

Among households with persons aged 65 years and over, the share of "three generation" type families declined dramatically, whereas the sum of one-person and couple-only increased to exceed 50 percent (Figure 5, left side). On the other hand, average size of a family declined steadily (Figure 5, right side), reflecting the increase in the share of nuclear and one-person family. The decline in the number of family members per households was larger for rural areas

\footnotetext{
${ }^{6}$ In our empirical analysis, population is considered as the main variable for housing demand. The relationship between households and population is reported in Annex A.
} 
(-31.9 percent) compared to that in large cities (-28.2 percent). This reflect that younger generations in family members left to other part of the same prefecture or moved out, whereas older (parents) generation stayed in the prefecture. ${ }^{7}$ In terms of the change in number of households, we observe that major cities experienced a greater increase in the number of household (115.6 percent) compared to other areas (18.3 percent).

\section{Housing Price Developments in Japan}

In this section, we document the development of house prices in Japan, focusing on the differences across regions and types of housing.

At the aggregate level, using the residential land price as a proxy for house prices, house prices in Japan have experienced dramatic booms and busts. During the high growth periods with economic expansion in the 1970s and 1980s, house prices in Japan steadily increased. Then, the 'Bubble Period' in the late 1980s to early 1990s started. Since 1988, house price appreciation intensified very rapidly, with an annual average increase of 20 percent. The bubble burst in 1991, which was accompanied by a sharp fall in house prices. Since then, the house price in Japan has been on a steady downward trend, except for a short period of a "Mini bubble (2002-2008)." Since the beginning of Abenomics, price started to increase gradually (increasing by 2.7 percent since 2014 and 0.7 percent in 2018). With the recent increase in house prices, the current level recovered to the level in 2013. Annex B describes each period in more details.

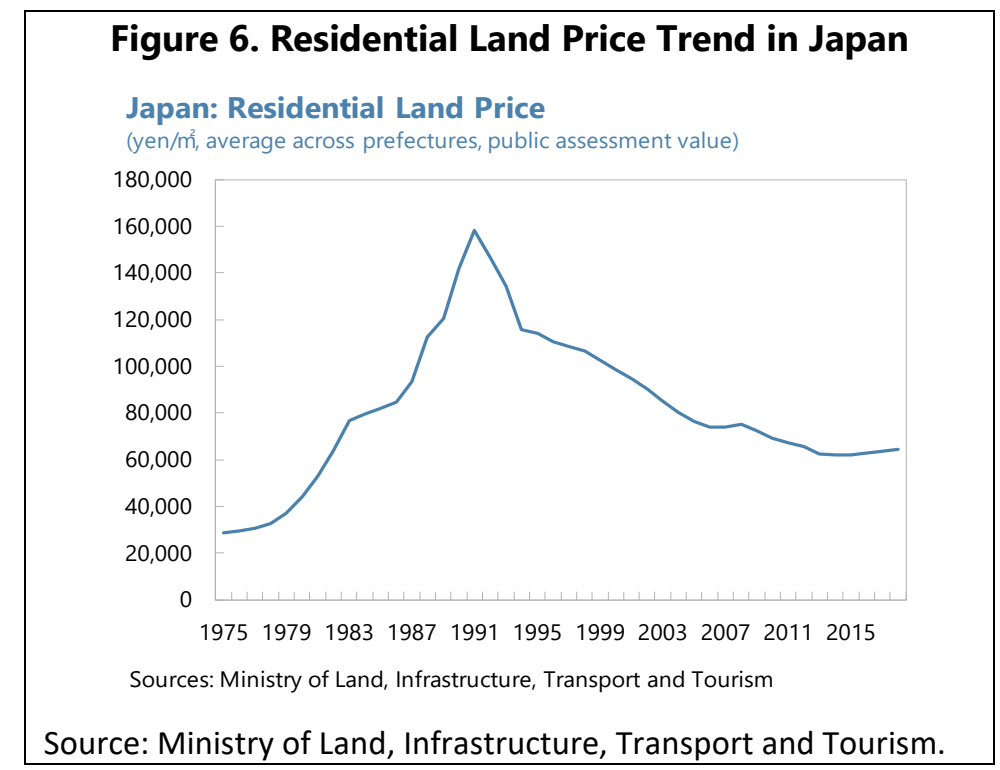

\section{A. House Price Changes Across Prefectures}

How have house prices evolved in different prefectures? Figure 7 shows the growth rate of house prices by prefecture using different time periods. The map on the left shows cumulative price changes between 2002 and 2018. It shows that compared to the level of house prices in 2002, all prefectures, except for Tokyo, experienced a decline in house prices (from -5 to -15

\footnotetext{
${ }^{7}$ Elderly dependency ratio is significantly lower in large cities and higher in rural areas.
} 
percent). By contrast, the map on the right shows cumulative house price changes since 2014 by prefecture. Compared to the map on the left, numerous prefectures experienced house price appreciations in recent years, an average 1.9 percent nationwide since 2013. The magnitude of price change, however, varies greatly across prefectures: greatest gains seen in Miyagi, Fukushima by 18 percent (due to the low base effects related to the earthquake), Tokyo (16 percent) while losses have been recorded in Akita (-6.5 percent), Shimane ( -5.5 percent) and Yamanashi (-4.8 percent). In general, house prices in large cities and tourist destinations exhibited price appreciations, especially led by constructions of condominiums. This could be due to various factors including construction booms prior to the Tokyo Olympics scheduled originally in 2020 and demand for high investment returns in a prolonged low-interest rate environment, among other factors. For example, Hokkaido has attracted domestic and international investment in skiing resorts, which has driven up commercial land price by $60 \%$ in 2018 and residential land prices as well.

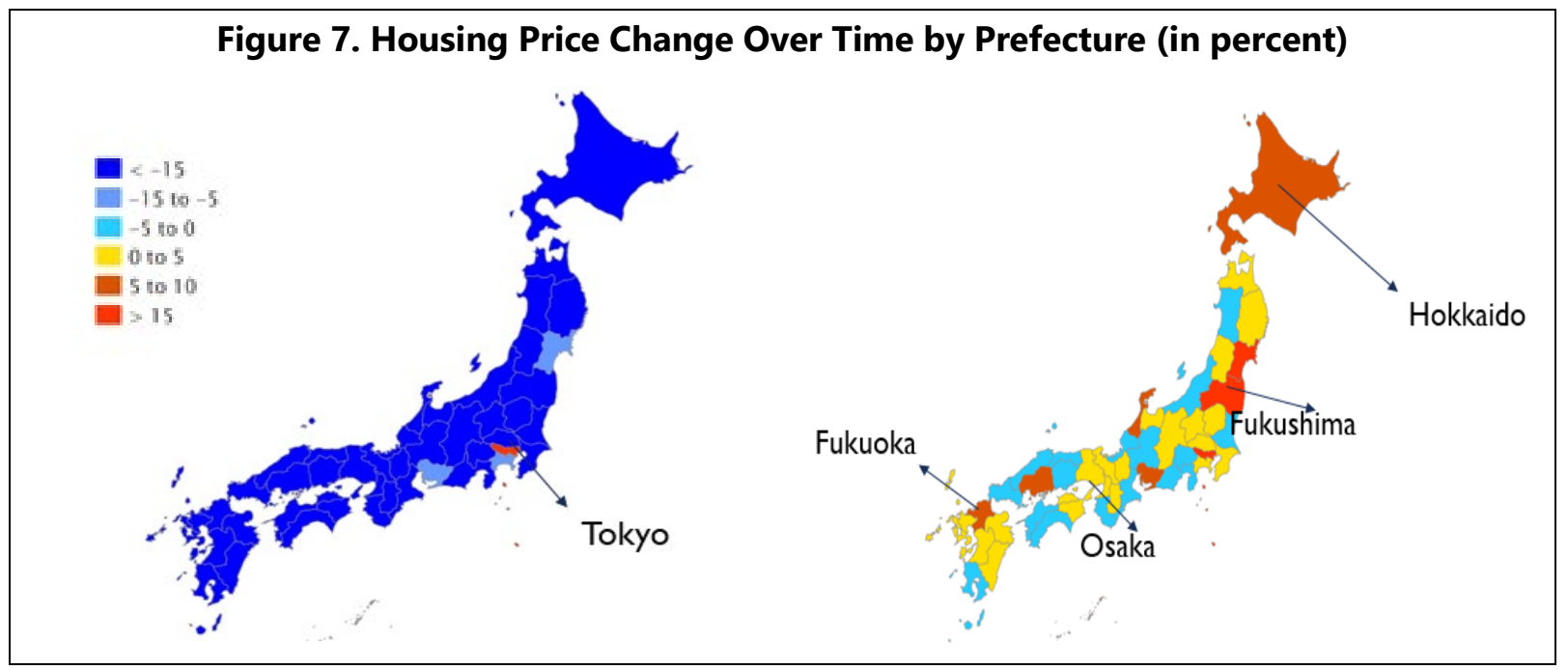

\section{B. House Price Changes by Housing Type}

Expanding on the recent house price developments depicted in the right map of figure 7, in this section, we assess an important aspect of recent house price developments, which is a large dispersion of price changes across different types of housings. In sum, condominium prices experienced a steeper price appreciation compared to detached houses, particularly in large metropolitan areas. Condominium prices have increased by 23 percent at the national level since 2013. In particular, condominium prices in Tokyo increased by 45 percent since $2013 .{ }^{8}$ For detached houses, by contract, the increase was only 4.2 percent since 2013 (Figure 8).

\footnotetext{
${ }^{8}$ IMF (2017) concluded that condominium prices appear to be moderately overvalued in Tokyo, Osaka, and several outer regions, exceeding the values predicted by fundamentals by 5 to 10 percent.
} 
Figure 8. Housing Price Movements by Property Types

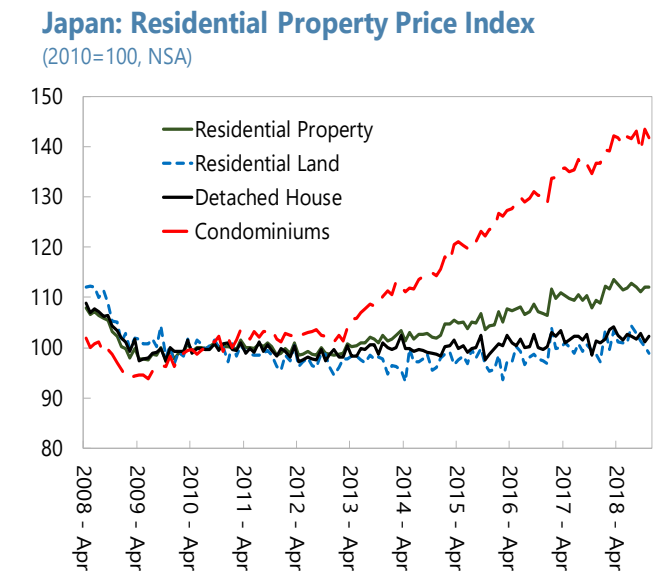

Sources: Ministry of Land, Infrastructure, Transport and Tourism

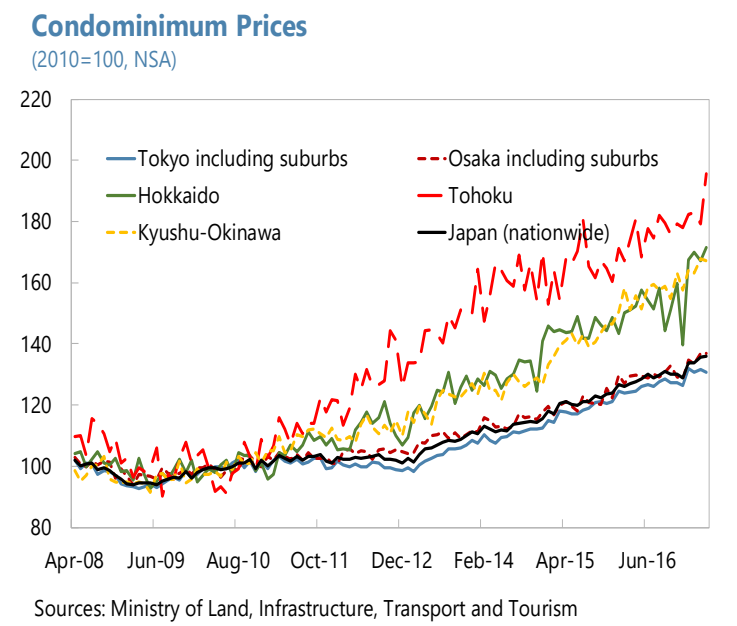

Source: Ministry of Land, Infrastructure, Transport and Tourism.

Some key drivers behind the steep rise in condominium prices include: (1) wealthy households investing in high-rise condominiums for inheritance tax avoidance purposes; (2) search-foryield motive by financial institutions and individuals in low-interest environment created by aggressive monetary easing; and (3) an increase in foreign investors.

- Tax incentives: The inheritance tax assessment for residential properties is done separately for land and for dwellings. Land assessment is based on the portion of holdings of land. As a result, the tax on land is likely to be smaller for higher dwelling buildings with more residents (such as high-rise condominium buildings), and tax assessment value becomes smaller for owners of condominiums. In addition, assessed value of dwellings (condominium units and houses) is usually lower than market value, providing incentives for the owners to leave real estate for investments in alternative financial assets (see Annex C for more details).

- High investment returns: Among different types of housing, condominiums have enjoyed the largest price appreciation due to several reasons. First, the secondary market for condominiums is relatively well developed than that for detached houses, therefore the market is stable and deep in the sense that it is easy to transact condominiums in Tokyo metropolitan areas. Second, the added benefit of owning condominiums is that condominiums could be easily rented out. Finally, with the expectation that condominium prices will rise further, returns from investment in condominiums are in general much higher than the real rates. ${ }^{9}$

- Foreign investment: Foreign investors have invested aggressively in certain segments of the Japanese real estate market since 2016. As shown in Figure 9, transaction volume of

\footnotetext{
${ }^{9}$ According to Japan Real Estate Institute projections (May 2019) on prices and rents of new condominiums in Tokyo's 23 wards, prices are expected to continue rising until 2020 and start to decline afterwards. Rents are projected to continue a very marginal but gradual increase until 2025.
} 
the Japanese real estate investment trust (J-REIT) has been steadily increasing since 2014, and the market has attracted international investors. The total acquisition of commercial real estate by foreign investors reached approximately $¥ 680$ billion in the second half of 2017 , the second highest after slightly above $¥ 800$ billion recorded in the first half of 2007 .

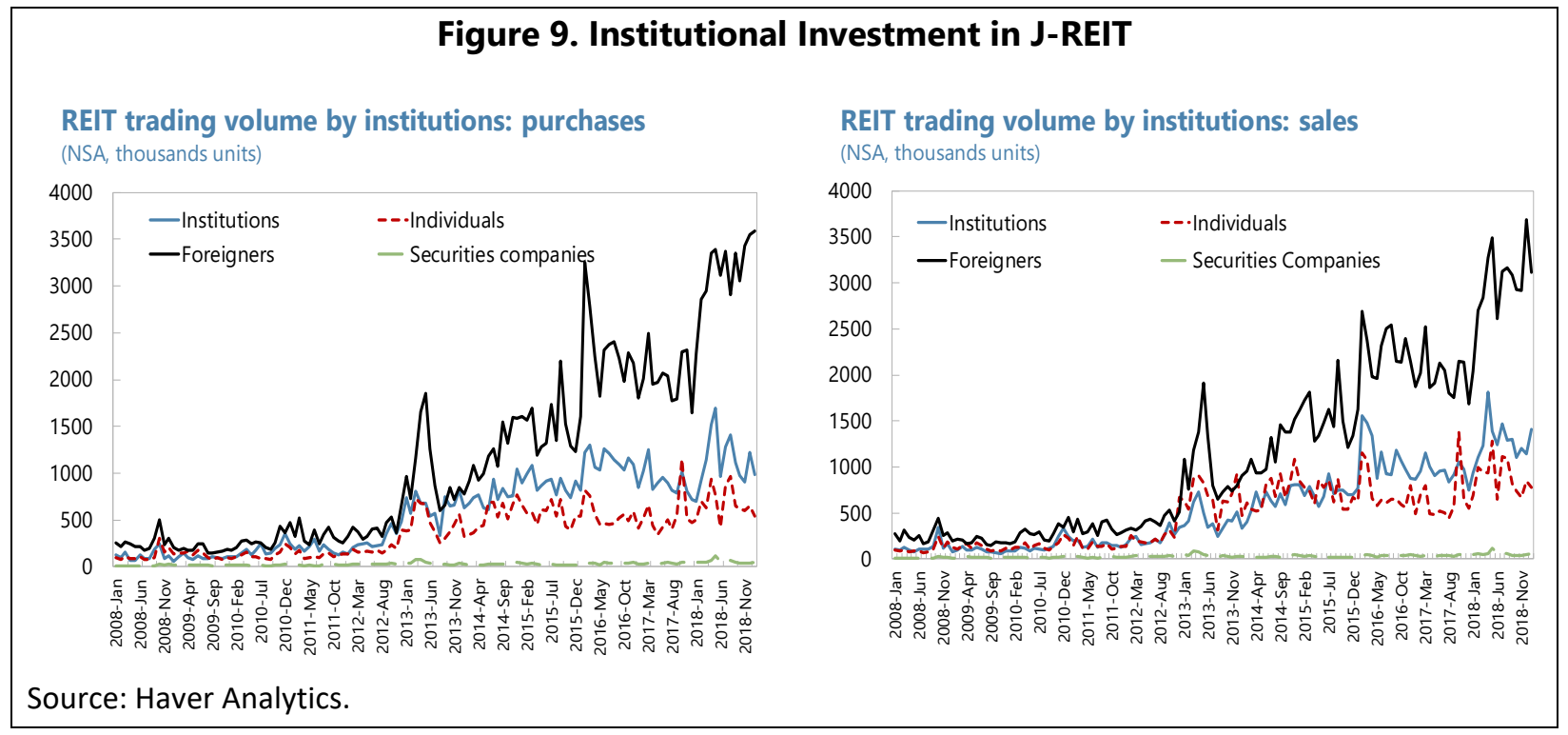

\section{Tokyo Story}

Tokyo and its surrounding prefectures stand out in terms of population flows and housing price changes, which shows the opposite trend relative to all other prefectures in Japan. Why is Tokyo special?

The trend of population concentration to Tokyo and other urban cities in the Tokyo Metropolitan area has continued and, in some sense, have even accelerated, despite the population decline in Japan. In fact, population migration to Tokyo never ceased. ${ }^{10}$ In terms of house prices, Tokyo is the only region where land house price increased despite the bubble crash as shown in Figure 7. Indeed, housing demand seems to have exceeded supply in Tokyo. Figure 10 shows the housing start and vacancy rates by prefectures to proxy for the relative supply and demand for houses. As expected, housing start is highly correlated with population and Tokyo has the highest number of housing start. At the same time, vacancy rate is low in Tokyo, suggesting high demand for houses.

\footnotetext{
${ }^{10}$ RIETI Policy Discussion paper Series 19-P-006 (in Japanese) discusses regional-urban discrepancy and migration across prefectures.
} 
Figure 10. Supply and Demand in Tokyo Housing Market

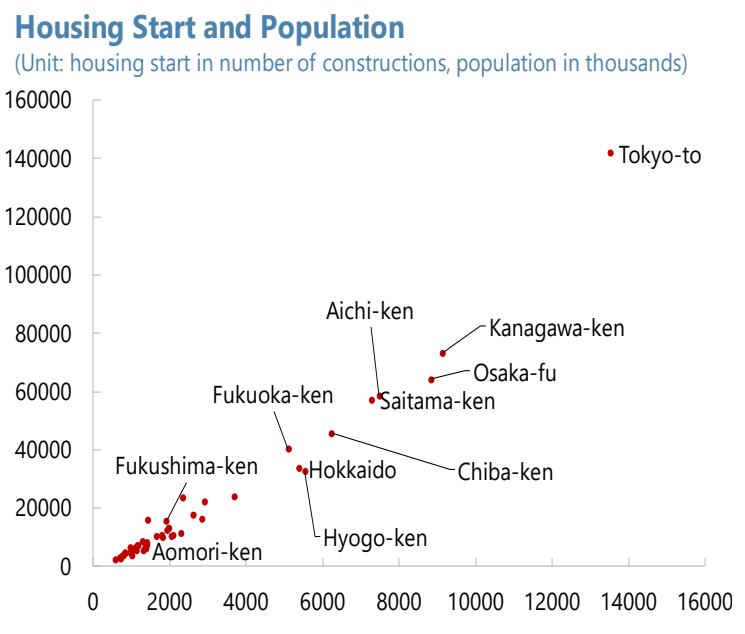

Sources: Cabinet Office, Ministry of Land, Infrastructure, Transport, and Touris

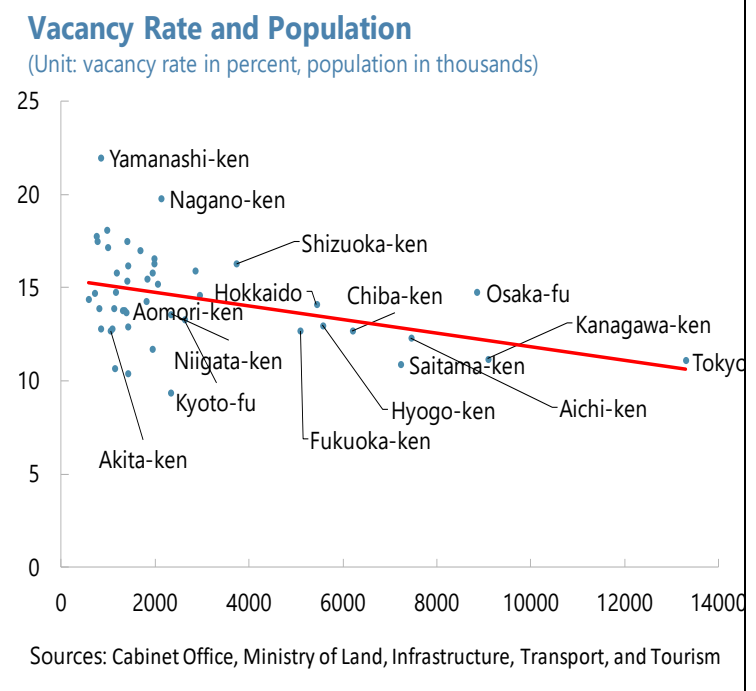

Inbound migration to the Tokyo area is an important demand side factor. Agglomeration of businesses contributes to an increase in commercial property prices, which in turn pushes up residential property prices. Another channel that contributes to an upward pressure of house prices is the higher income offered in large cities, which increases the affordability of house.

Supply-side factors could also explain the price increase in Tokyo, which includes the increased supply of new condominiums, whose prices rose more steeply compared to other types of housing, as we discussed in the previous section. There may be various reasons underlying the increased number of constructions of new condominiums:

- Market Structure of Condominium Developers. Recently, there has been an increase in the market share by major developers in Tokyo area. The market share of major seven developers in the number of condominium sales was relatively stable at about 20 percent until 2007. Since then, it increased to close to 50 percent in $2017 .{ }^{11}$ It implies that the housing price is more sensitive to the supply decisions of condominiums by these major market players. As the developers have the incentive to raise prices and control supply to support prices, this increases the likelihood that housing (condominium) prices will remain elevated. In fact, Figure 11 shows a reverse relationship between condominium prices and the supply of newly-built condominiums in the Tokyo metropolitan area. ${ }^{12}$

\footnotetext{
${ }^{11}$ Japan Real Estate Institute, Market Report, 2017H2.

${ }^{12}$ Historical monthly data of new condominium prices of Tokyo and Osaka (Land Institute of Japan Co.) reveal that new condominium prices in Tokyo are approaching those at the peak of the bubble in 1989, whereas it is not the case for other urban areas. For example, new condominium prices in Osaka metropolitan area have been relatively stable and never recovered to the bubble-era level as yet.
} 
- Tourism. Increased construction activities related to tourism: Tokyo has enjoyed a large inflow of tourists (see Nguyen 2020). The expectations of the 2020 Summer Olympics ${ }^{13}$ spurred expectations for economic booms in Tokyo metropolitan area.

Figure 11. Tokyo Metropolitan Area: New Condominium Supply and Prices

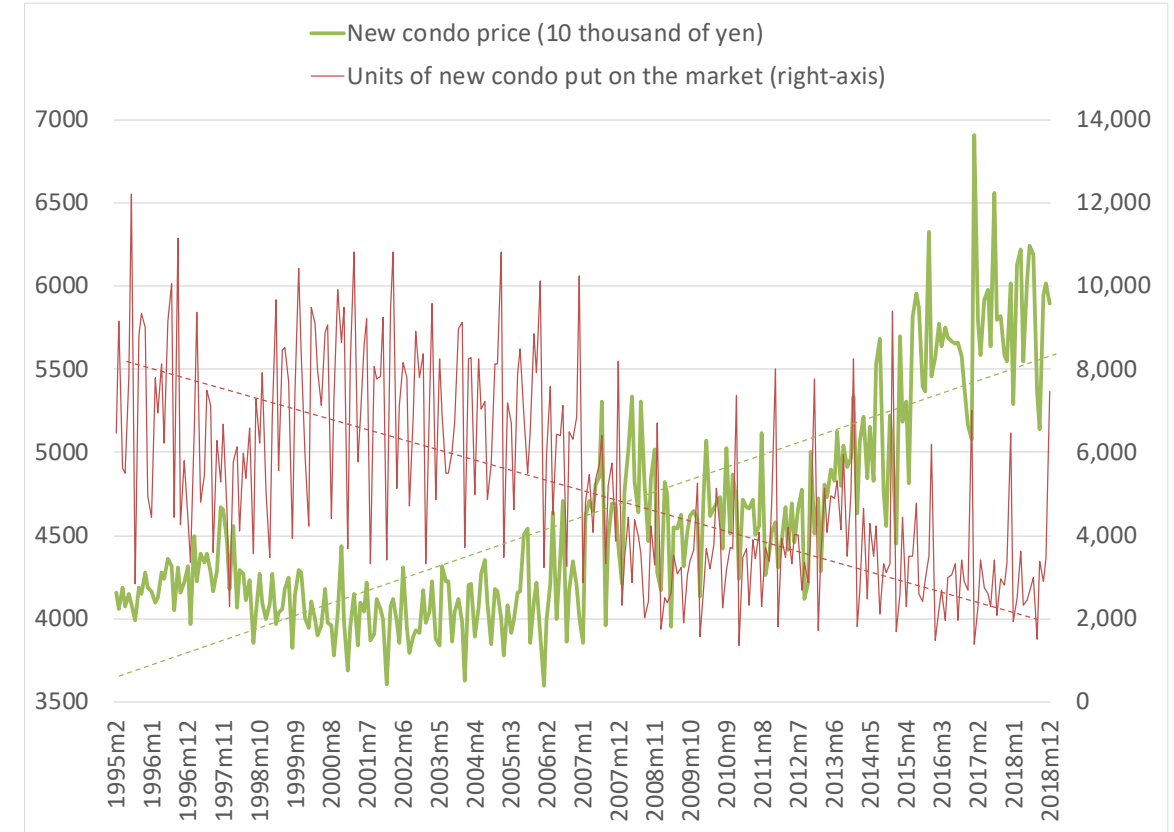

Source: Land Institute of Japan Co.

In addition to demand and supply factors, there are other drivers that encourage activities in the real estate market in general.

- Low interest rate environment. The ultra-low interest rate policy by the Bank of Japan along with relatively low returns from equity and other financial markets boosted investment in real estate that has generated higher returns. Low mortgage rates helped spur demand for houses, reflecting population migrations into Tokyo and other urban areas whereas rural regional areas struggled with sluggish recovery after the collapse of the bubble.

- Inheritance tax incentives. As mentioned in the previous section, the inheritance tax incentives have contributed for an increased demand for condominiums (Annex $\mathrm{C}$ for more details).

\footnotetext{
${ }^{13}$ In March 2020, the postponement of the Tokyo Olympics by one year was officially announced, due to the COVID-19 pandemic.
} 


\section{Modeling Population Growth and Housing Prices}

In this section, we establish an empirical relationship between population change and housing price changes in Japan. ${ }^{14}$ Our analysis will focus on the sample from 1975 to understand the long-term and stable relationship between the two variables, rather than focusing on most recent developments.

\section{A. Theoretical Framework}

Conceptually, a simple demand and supply model of housing market describes that a shrinking and declining population would lead to lower house prices - the excess supply of houses due to sales by elderly people exceeds the demand for houses by young working generation. In Japan, due to a population decline and aging in many areas, the downward pressure on a demand curve should be large and the supply curve may shift rightward due to an increase in sales by elderly. The shrinking population should have added a further downward trend on house prices, on top of the low-growth period after the burst of the bubble economy in early 1990s (Kobayashi 2016).

The theoretical underpinning of this section is the durable housing model by Glaeser and Gyourko (2005). The key insight is that the sensitivity of house prices changes to population change is asymmetric - population loss is accompanied by a larger decline in housing prices than the size of housing price increase with the same size of population increase. This is due to the durability of housing, whereby housing supply is elastic when new houses are built, while inelastic when houses need to be destroyed.

As a result, due to the durability of housing, the supply curve of housing is kinked: it is (relatively) easy to construct, but once constructed, it is not easy to reduce (or demolish) due to construction costs. An increase in population will be associated with house price increases, because demand for houses should rise. On the other hand, a decline in population, therefore a decline in demand for houses, will be associated with declining housing prices (Figure 12). The point of the durable housing model is that the impact of demand on the increase and decrease of prices are not symmetry: an increase in house price driven by increased demand is small as the supply adjusts elastically, while the decrease in house price driven by decreased demand is larger as the supply does not adjust elastically.

\footnotetext{
${ }^{14}$ Several studies that focused on the supply-side of housing market show that the number of houses provided is highly correlated with population growth as people naturally demand places to live. The correlation coefficient between log changes in housing units and population exceeds 0.9, according to U.S. data (Glaeser and Gyourko, 2005). In Japan, a similar observation can be made where house ownership increased during the baby boom generation period (see Saita, Shimizu, Watanabe (2013)).
} 
Figure 12. Nonlinear Relationship between Population Growth and House Price Changes

Case A: Large cities (Tokyo): Net inflows of population increase demand for houses, and house prices increase (P1). An upward shift in the supply curve leads to an increase in housing prices (P2).

$\mathrm{P}$ : housing price

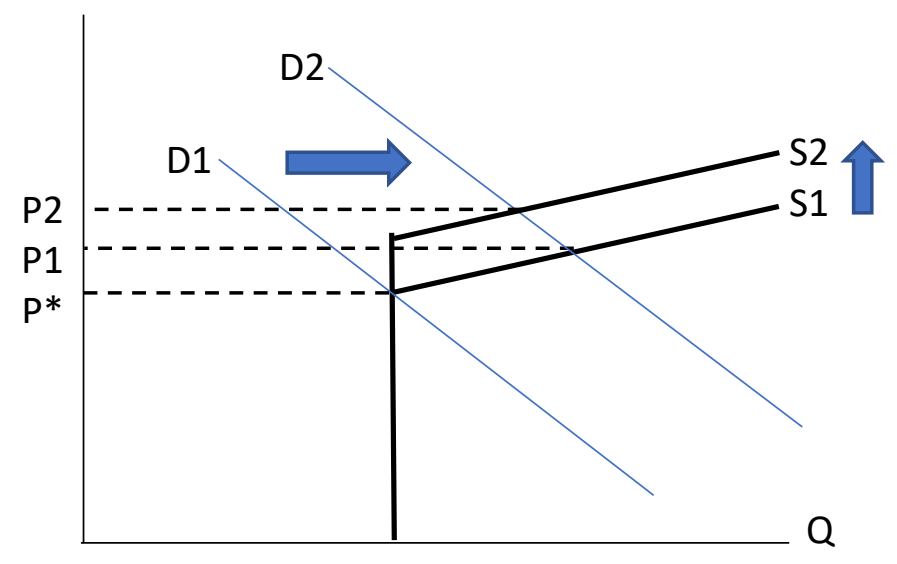

Case B: Rural areas: Population outflow lowers the demand for houses, and prices fall (P1). The supply of houses increases due to sales by owners who move out from the region, putting further downward pressure on house prices (P2).

$\mathrm{P}$ : housing price

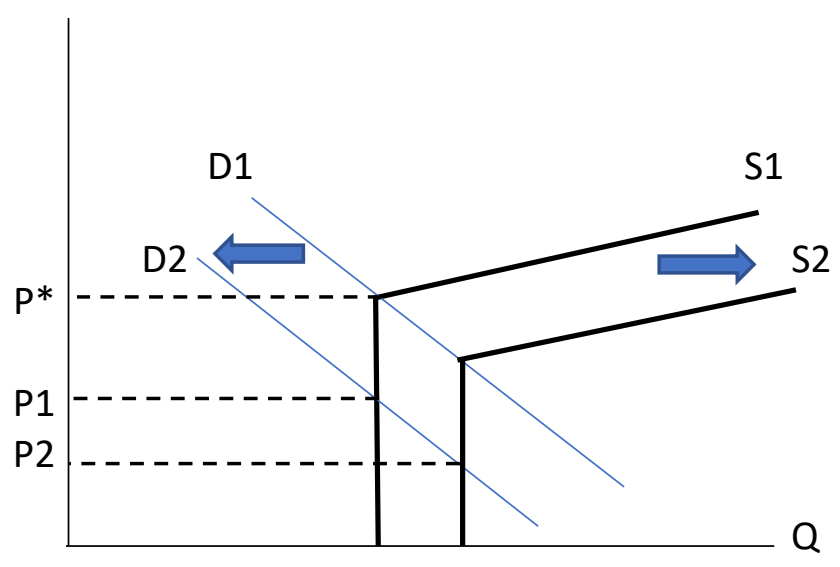

\section{B. Empirical Analysis}

Following Glaeser and Gyourko (2005), as explained in the previous subsection, we look at a non-linear relationship between housing price and population change in Japan. That nonlinearity is the difference in sensitivity between price changes and population growth, depending on population gain or population loss. Figure 13 depicts a simple correlation between the changes in house prices and net migration flows across regions over the last twenty years (orange line). The dotted red line represents the fitted line excluding Tokyo. The actual house price in Tokyo is well below what would have been predicted by the dotted red line. 
Figure 13. Changes in House Price and Net Migration Flows (1996-2018)

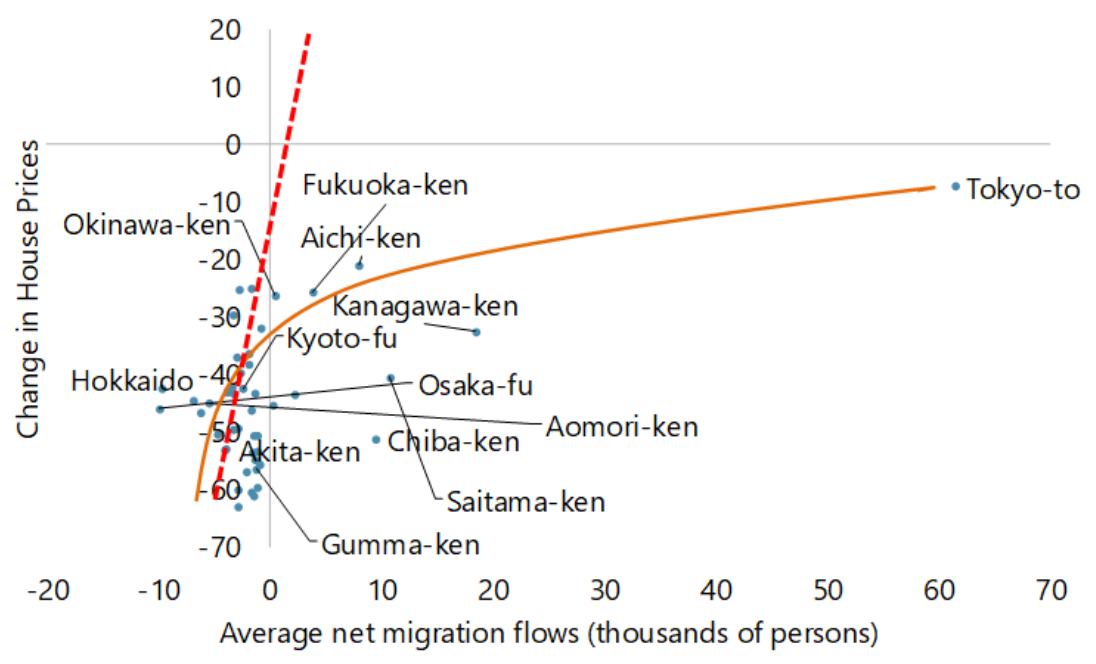

Sources: Ministry of Land, Infrastructure, Transport and Tourism; IMF staff calculations

With this background, our baseline regression specification is as follows:

$$
\Delta P_{i, t}=\alpha+\beta P O P L O S S_{i, t-1}+\gamma P O P G A I N_{i, t-1}+\varepsilon i t
$$

where $P$ is the publicly assessed residential land price adjusted for inflation (in $¥ / \mathrm{m}^{2}$ ) as a proxy for housing price; POPLOSS variable takes on a value of zero if prefecture $i$ 's population grew during the period $t$ and equals prefecture's actual percentage decline in population if the prefecture lost population during the period. Similarly, POPGAIN variable takes on a value of zero if prefecture $i$ experienced population loss during the period of $t$, and equals the actual population growth rate if the prefecture gained population. The expected signs of coefficients of $\beta$ and $\gamma$ are positive, and that $\beta>\gamma$. This implies that for a price decline is bigger $(\beta)$ for a given loss of population (POPLOSS $<0$ ) than a price increase $(\gamma)$ for a given population increase (POPGAIN $>0$ ). In order to account for the lagged impact of population on housing price, we use POPLOSS and POPGAIN of $t-1$ in the regressions.

For the robustness check, we test the following two baselines with additional controls:

$$
\begin{gathered}
\Delta P_{i, t}=\alpha+\beta P O P \text { LOSS }_{i, t-1}+\gamma \text { POPGAIN }_{i, t-1}+\delta \Delta O L D D E P_{i, t-1}+\varepsilon i t, \\
\Delta P_{i, t}=\alpha+\beta P O P L O S S_{i, t-1}+\gamma P O P G A I N_{i, t-1}+\delta \Delta O L D D E P_{i, t-1} \\
+\mu \Delta \text { vacancy }_{i, t-1}+\varepsilon_{i t}
\end{gathered}
$$

The following table show regression results based on panel data of the annual change in population and real land price across three different time periods: (i) 1975-2015, (ii) past two decades since the collapse of the asset bubble, covering 1996-2015; and (iii) more recent periods over 2010-2015 (Table 2). 
Results show that during 1975-2015 (column 1), the estimated coefficient for population loss is higher than that of population gain, confirming the prediction by Glaeser and Gyourko (2005) that housing price falls faster with declining population than it increases with increasing population. However, in more recent periods, while the correlation between house price decline and population decline stays robust, the relationship between house price increase and population increase disappears. This confirms the overall decline in housing prices across regions since the bubble burst, regardless of population growth.

In reality, negative effects on housing prices from population decline may be even larger than model predictions. The results suggest a larger decline in housing price associated with population loss than a housing price increase with the same size of population gain. Given the shrinking population in many prefectures, a further housing price decline could be a mediumand long-term trend. The linkage between population loss and a housing price decline could lead to a vicious cycle - residents expecting a housing price decline may sell their houses and have less incentives to own houses, which will add to already-existing oversupply for houses and create further downward pressures on housing prices.

\begin{tabular}{|c|c|c|c|c|c|c|c|c|c|}
\hline \multirow[b]{3}{*}{ VARIABLES } & \multicolumn{9}{|c|}{ Table 2. House Price Changes and Population Change } \\
\hline & \multicolumn{9}{|c|}{ Dependent variable: $\% \Delta$ real land price } \\
\hline & \multicolumn{3}{|c|}{$1975-2015$} & \multicolumn{3}{|c|}{$1996-2015$} & \multicolumn{3}{|c|}{$2010-2015$} \\
\hline POPLOSS & $\begin{array}{c}4.698^{* * * *} \\
(0.908)\end{array}$ & $\begin{array}{c}4.963^{* * *} \\
(0.975)\end{array}$ & $\begin{array}{c}5.126^{* * *} \\
(1.043)\end{array}$ & $\begin{array}{c}4.563^{* * *} \\
(1.175)\end{array}$ & $\begin{array}{c}4.557^{* * * *} \\
(1.183)\end{array}$ & $\begin{array}{c}4.570^{* * *} \\
(1.168)\end{array}$ & $\begin{array}{c}3.739^{* * * *} \\
(0.746)\end{array}$ & $\begin{array}{c}3.716^{* * *} \\
(0.782)\end{array}$ & $\begin{array}{c}3.928^{* * *} \\
(0.862)\end{array}$ \\
\hline POPGAIN & $\begin{array}{c}2.715^{* * *} \\
(0.674)\end{array}$ & $\begin{array}{c}2.456^{* * *} \\
(0.750)\end{array}$ & $\begin{array}{c}3.406^{* * *} \\
(0.890)\end{array}$ & $\begin{array}{l}-0.660 \\
(1.549)\end{array}$ & $\begin{array}{c}-0.773 \\
(1.561)\end{array}$ & $\begin{array}{l}-0.838 \\
(1.578)\end{array}$ & $\begin{array}{l}-3.816^{*} \\
(2.139)\end{array}$ & $\begin{array}{l}-3.666 \\
(2.252)\end{array}$ & $\begin{array}{l}-3.354 \\
(2.368)\end{array}$ \\
\hline$\% \triangle O L D D E P$ & & $\begin{array}{l}-0.278 \\
(0.238)\end{array}$ & $\begin{array}{l}-0.388 \\
(0.240)\end{array}$ & & $\begin{array}{l}0.234^{* *} \\
(0.100)\end{array}$ & $\begin{array}{l}0.227^{* *} \\
(0.106)\end{array}$ & & $\begin{array}{l}0.0273 \\
(0.154)\end{array}$ & $\begin{array}{l}0.0675 \\
(0.176)\end{array}$ \\
\hline$\% \Delta$ Vacancy rate & & & $\begin{array}{l}-0.325^{*} \\
(0.181)\end{array}$ & & & $\begin{array}{l}-0.0389 \\
(0.107)\end{array}$ & & & $\begin{array}{c}0.635 \\
(0.666)\end{array}$ \\
\hline Constant & $\begin{array}{c}-0.0943^{* * * *} \\
(0.00938)\end{array}$ & $\begin{array}{c}-0.0842^{* * * *} \\
(0.0142)\end{array}$ & $\begin{array}{l}0.0613^{* * *} \\
(0.0153)\end{array}$ & $\begin{array}{c}-0.0148^{* * *} \\
(0.00402)\end{array}$ & $\begin{array}{c}-0.0230^{* * *} \\
(0.00581)\end{array}$ & $\begin{array}{l}-0.0215^{* * * *} \\
(0.00736)\end{array}$ & $\begin{array}{c}-0.0107^{* *} \\
(0.00416)\end{array}$ & $\begin{array}{c}-0.0122 \\
(0.00965)\end{array}$ & $\begin{array}{r}-0.0172 \\
(0.0121)\end{array}$ \\
\hline Observations & 1,927 & 1,880 & 1,739 & 846 & 846 & 846 & 188 & 188 & 188 \\
\hline R-squared & 0.577 & 0.579 & 0.584 & 0.345 & 0.349 & 0.350 & 0.571 & 0.571 & 0.572 \\
\hline Number of code & 47 & 47 & 47 & 47 & 47 & 47 & 47 & 47 & 47 \\
\hline Fixed effects & Y & Y & Y & Y & Y & Y & Y & Y & Y \\
\hline Time effects & Y & Y & Y & Y & Y & $Y$ & $Y$ & $Y$ & $Y$ \\
\hline $\begin{array}{l}\text { Robust standard } \\
{ }_{* * *} p<0.01,{ }^{* *} p<\end{array}$ & $\begin{array}{l}\text { s in parenth } \\
* p<0.1\end{array}$ & heses & & & & & & & \\
\hline
\end{tabular}

\section{Policy Implications}

The empirical finding on the non-linear relationship between population changes and house prices imply that house prices in Japan for most regions are on a downward trend, in line with shrinking population. The downward trend of house prices is expected to incur negative impacts on many sectors of the economy. For example, households' financial and non-financial assets would be affected negatively due to a decline in house prices. For financial institutions, house price declines significantly affect their holdings of collateral values. This would add 
more burden on those already suffering from declining profitability of the industry. House price declines directly affect local governments by reductions in tax revenue from housing transactions. It would produce the second-round effect, quality and quantity of social spending in the area. This might accelerate population outflows, which further exacerbates the housing market and prices. This also raises an important underlying issue: why people are moving to large cities in Japan?

In this section, we first discuss the possible root causes of migration flows across prefectures that have contributed to the polarization of population concentration in Japan. Then we discuss the potential implication of house price declines on household sector by focusing on balance sheet effects. Finally, we discuss policy measures to tackle with potential overinvestment for housing supply in shrinking and uneven population dynamics and local government challenges.

\section{A. Why Move to Large Cities?}

One of the key issues facing most of the prefectures in Japan, except for some major cities, is the brain drain that comes with population outflows. With the aging population, rural regions of Japan are experiencing outbound migrants to larger cities who leave their towns and cities for better education and job opportunities. Availability of city amenities, such as numbers of colleges and universities, hospitals and other facilities, is incomparably higher in major cities. ${ }^{15}$ These factors are one of root causes of the regional disparities in population dynamics and the continuous inflows of population into large cities from rural areas.

Population migration into large cities, especially by the young generation, affects the housing market through the channel of human capital accumulation in the region. There exists a large variation across prefectures in terms of the share of population with higher education - for prefectures such as Akita and Aomori, the share of population with university degrees or higher make up of about 5 percent of the population. This contrasts with Tokyo or Kanagawa (a prefecture in the suburb of Tokyo) that has close to 20 percent of its total population with higher education (university degree or above).

\footnotetext{
${ }^{15}$ For example, the number of general hospitals per 100,000 persons is more or less the same across prefectures, although the numbers are higher in Shikoku and Kyushu areas (Japan average is 5.8). However, the number of general hospitals per $100 \mathrm{~km}$-sq of inhabitable area varies largely across prefectures. The numbers in broader Tokyo and Osaka areas are seven times larger than Japan's overage of 6.0. The lowest three are found in Iwate (2.1), Akita (1.7), and Yamagata (1.9). Data are as of 2016, from social indicators by prefecture, Ministry of Internal Affairs and Communications.
} 
Figure 14. Education and House Prices

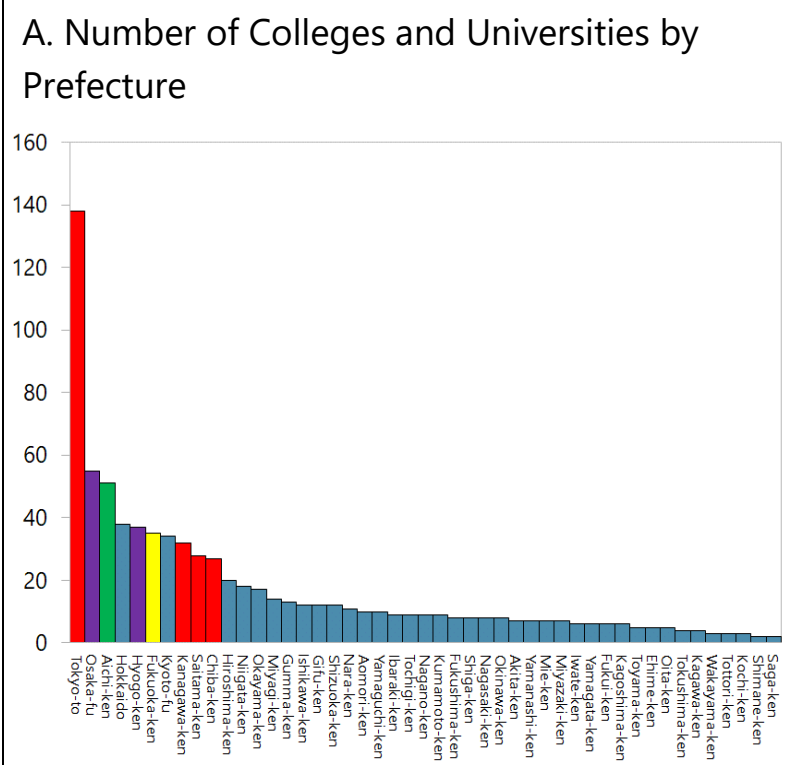

B. Human Capital and Housing Price Changes

Human Capital and Housing Price Change

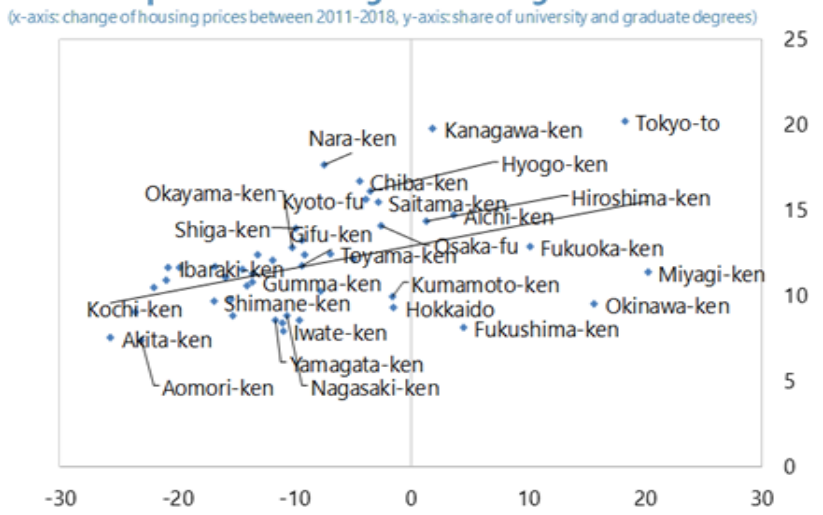

Sources: Statistics Bureau of Japan, IMF Staff Calculations

Sources: Statistics Bureau of Japan, IMF Staff calculations

Figure 14 shows that there is a positive correlation between housing price changes and the share of educated population. This may reflect a higher affordability with workers in the cities with higher income. Some studies show that skilled workers are better generating growth in endogenous amenities, increasing the value of price (Shapiro, 2006; Glaeser and Saiz, 2004). In any case, brain drain could exacerbate the regional disparities in terms of growth and welfare, and therefore housing price dynamics.

\section{B. Implications for Household Balance Sheets}

House prices have an important role in household wealth through house ownership in Japan. According to the National Survey of Family Income and Expenditure of 2014, dwelling related liabilities (purchase of house and/or land) consists of about 75 to 90 percent of total household liabilities. Therefore, changes in housing prices have important implications on household wealth - a collapse of housing price leads to a deterioration of households' net wealth (both net financial and nonfinancial assets), whereas their financial liabilities are less affected.

Households in different regions of Japan may be affected differentially, as house price dynamics vary across regions. For instance, if rural prefectures of Japan experience a larger decline in housing prices compared to metropolitan areas, the value of nonfinancial asset for households in rural areas becomes much lower for house owners. In other words, the households balance sheet is more severely affected for households in rural areas than those in urban areas. This may lead to wealth inequality between urban and rural areas. 
Looking at historical experience, the household balance sheet was negatively affected during the periods after the bubble crash, when the housing price was on a declining path. Figure 15 suggests that household balance sheets were affected largely from a huge decline in the land value during the low-growth period. The decline in the land value more than offset an increase in the balance of net financial assets of households between 1994 and 2017. ${ }^{16}$ Unfortunately prefectural-level data comparisons are not available: however, we can easily assume that balance sheets of households in rural areas should be affected more severely than those in large cities, given larger land (and house) price declines in rural areas, whereas there are likely more even changes in net financial assets (for example, stock prices) across regions.

Assume that financial assets in households balance sheets are equally affected across Japan, then negative impacts from the nonfinancial asset pose a larger burden on households in population declining prefectures. Since houses and lands are one of assets inherited intergenerationally, house price declines imply that inequality could transmit intergenerationally, and inequality could expand through house price declines. ${ }^{17}$

Figure 15. Change in Household Balance Sheet Values 1994-2017 (Trillion Yen)

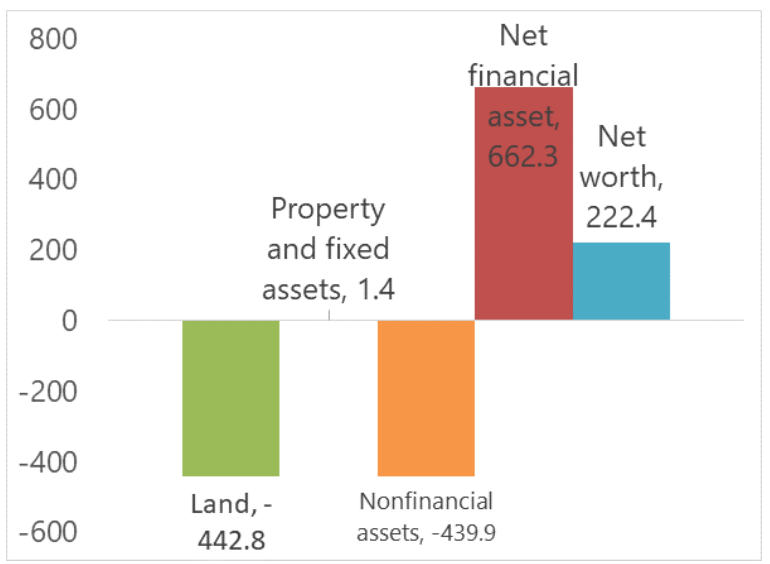

Source: The Cabinet Office, Government of Japan, Economic and Social Research Institute (ESRI), and IMF staff calculations. The household sector includes Private Unincorporated Enterprises (NPISH).

\footnotetext{
${ }^{16}$ Similar data from the OECD on financial and non-financial asset sectoral data is available only up to 2013. There is a minor difference in the household sector coverage: the CAO (the Cabinet Office) data include private unincorporated enterprises in addition to households, whereas OECD data are of households only. Comparisons between CAO and OECD data using data samples from 1995 to 2013 are almost identical, with a minor difference in changes in the net financial asset value: which may reflect valuation changes of private enterprises' asset valuation. The decline in the land value as well as nonfinancial assets are quite similar between the two data sources.

${ }^{17}$ In fact, a U.S. study shows that the size distribution of direct financial transfer is highly skewed and affects intergenerational redistribution. A counterfactual experiment where inheritances and inter vivos transfers are equally distributed across the population shows that the top 10 percent of families sorted by wealth would actually hold 40 percent of wealth, which is close to a half of 73 percent of the wealth actually owned by these 10 percent families in 2016. (FEDS Notes, June 01, 2018).
} 


\section{Overinvestment and Housing Market Policy}

One of the issues of housing market in rural areas of Japan experiencing population outflows is the over-supply of houses: that is, house supply does not decline to a level which clears the demand for houses and stabilizes house prices.

Weakening demand for houses (in general, with regional divergence) while continuing supply of new houses (especially in large cities) has generated an increasing number of abandoned/vacant houses (akiya) across regions. The number of vacant/abandoned houses and the vacancy rate of them have increased in the past decades and reached their historical highs of approximately 8.5 million houses throughout the country and 13.6 percent (Japan average) in 2018, respectively. ${ }^{18}$ Prefectures with a high ratio of akiya match those with large population outflows, which include Yamanashi (21.3 percent), Wakayama (20.3 percent), Nagano (19.5 percent), Tokushima (19.4 percent) and Kouchi (18.9 percent) (in Shikoku Island), and Kagoshima (18.9 percent) (in Kyushu Island). In contrast, the vacancy rate is lower in prefectures such as Tokyo, Kanagawa and Aichi.

There are several reasons behind the continued supply of new houses even though vacant houses are generated. For instance,

- Secondary market for detached houses is not well-developed and active. There are several factors that hamper the development of the secondary market that contribute to low transactions of used and vacant houses. One is people's preference for "newly built" over used houses. Tax treatments - such as conditions for income tax deductions on mortgage loans and fixed pro - are more favorable for newly built houses. Lack of ability to properly assess used house values hampers to determine accurate collateral values of the property. This leads to lenders (banks) become more reluctant to make loans and buyers may not be able to have enough access to a mortgage.

- Property tax issues. Vacant houses have not been demolished, because the tax assessment for detached houses or any building structure (plus land) was much lower than that for the land only. Therefore, there was no incentive to demolish houses, unless the owners have plans to sell the land and the building altogether (Annex C). ${ }^{19}$

Recognizing problems related to vacant houses, a new law was introduced in May 2015 (“Akiya Taisaku Tokubetsu Sochi Hou", Vacant Houses Special Measures Act; official announcement in November 2014). The law aims to provide local/municipal governments

\footnotetext{
${ }^{18}$ Ministry of Internal Affairs and Communications, 2018 Survey.

${ }^{19}$ Property tax is charged on the land and structures at $1.4 \%$ of the taxable base. There is an exceptional treatment for small residential properties wherein the taxable base on the land is reduced to one sixth of the appraised value if there remains a residential structure on it (the background for this is to accelerate the high utilization of land by giving an incentive to home construction). This was cited as one of the causes of the high vacancy rate in Japan because, even after the property is not occupied and had better be demolished, the owner of the property had an incentive to leave the property as it is to enjoy a lower property tax rate. To remove such poor housing stock, new legislation was enacted in 2015 to accelerate the removal of such vacant houses.
} 
legal powers to help them deal with abandoned houses. ${ }^{20}$ Several actions to tear down unoccupied and dangerous houses have been taken, although the progress has been very slow. In addition, Ministry of Land, Infrastructure, Transport and Tourism (MLIT) launched a web-based system to provide information of "for sale" and "for rent" of public assets. ${ }^{21}$ These are attempts to facilitate and activate use of public assets in face of large fiscal deficits at the local government level: however, it does not cover abandoned houses and buildings in private sector. Going forward, there needs a holistic policy strategy — including urban planning, precise projections on supply of and demand for houses, mortgage and other real estate-related regulations, tax policies, and even private-public partnerships - are needed to make the best use of non-used investment assets.

\section{Conclusion}

In this paper, we study regional differences in population dynamics and try to understand how demographic changes influence housing market prices in Japan.

First, we document how demographic trends and housing prices have evolved over time in Japan across regions. We found that demographic trends are important underlying factors behind the growing regional dispersion. Different regions in Japan are experiencing demographic transition at a different pace. That is, while population is declining in most prefectures due to a low fertility rate and outbound migration, population is growing in key major cities and surrounding regions with inbound migration, contributing to a large disparity in population concentration across regions. At the same time, housing prices have declined persistently across regions since the early 1990s, after the bursting of the bubble. The speed and rate of declines, however, exhibit regional disparities - larger cities experienced relatively smaller price declines than other regions. Only Tokyo (and a broader area of Tokyo) experienced an early recovery from the continued price fall—due to factors such as condominium construction booms and investment expectations related to the 2020 Tokyo Olympics. After 2014, finally, numerous prefectures experienced the first housing price appreciation since the beginning of Abenomics.

Second, we ask to what extent demographic trends are drivers of housing price dynamics in Japan. Our empirical analysis based on prefectural-level data shows that there exists an asymmetric relationship between changes in housing prices and population growth-housing prices fall faster with a declining population than it rises with an increasing population. This result proves the durability of housing, that is, once a house is constructed, it is not easy to demolish. Prefectures that suffer from population outflows suffer a large(r) decline in

\footnotetext{
${ }^{20}$ Empty and abandoned houses that may pose health and/or physical danger risks to the community are categorized as "specially designated vacant houses." The new law allows municipal officials to order the demolition of these houses. In principle, the authorities can request the owners to eliminate the risk sources, and demolish the houses if owners refuse. However, there are strict procedures to follow, and there were concerns that the legislation is not enough to address the problems.

${ }^{21}$ The public assets include old school buildings, government dormitories, and publicly held lands. The websites are managed by two private companies, Lifull Co., Ltd. and AtHome Co., Ltd. The MLIT also organizes a separate platform to provide information provision on public real-estate on their website, (Japanese only), at http://www.mlit.go.jp/totikensangyo/totikensangyo tk5 000102.html.
} 
housing prices, whereas house price declines in large cities such as a broader area of Tokyo, Osaka, and Fukuoka regions, have been limited.

The greater concern ahead is a vicious cycle leading to greater regional disparities, as lower housing prices in rural areas trigger more population outflows on the one hand, and an extreme population concentration in selected few cities raises prices, on the other hand. Even with some recovery in the housing market due to Abenomics and corrections from the postbubble housing price dynamics, the long-term trend of regional housing prices is not positive.

This may become a macro-critical issue over the long run. Housing market and real estate prices are one important channel through which demographics could affect the Japanese economy. Prefectures that have population outflows are experiencing 'brain drains' and suffer from productivity losses due to human capital loss. In addition, dwelling-related liabilities (purchase of house and/or land) constitute about 75 to 90 percent of total household liabilities, and land and real estate are strong collateral for household and business lending. Therefore, a fall in housing prices will have important implications for household wealth and affect the health of household and bank balance sheets. Declining house prices could pose further pressure on the already weakening balance sheets of some regional banks. There could arise potential negative spillovers from sharp declines in condominium and commercial real estate prices which could affect corporate and household debt.

Policies to address regional disparities and prevent an excessive fall in housing prices in rural areas are crucial. These include policy measures to promote more even growth across regions and regional revitalization to retain and attract population inflows into rural areas. In addition, policies on the supply of housing that factor in future demographic trends to avoid potential over-investment in real estate, and policies to help spur transactions in secondary markets to reduce vacant houses, will be important. 


\section{REFERENCES}

Colacelli, Mariana and Emilio Fernandez Corugedo, 2018, "Macroeconomic Effects of Japan's Demographics,” IMF Working Paper 18/248, International Monetary Fund, Washington DC.

Feiveson, Laura and John Sabelhaus, 2018, "How Does Intergenerational Wealth Transmission Affect Wealth Concentration?” FEDS Notes, June 01, 2018.

https://www.federalreserve.gov/econres/notes/feds-notes/how-does-intergenerational-wealthtransmission-affect-wealth-concentration-20180601.htm

Glaeser, Edward L. and Joseph Gyourko, 2005, "Urban Decline and Durable Housing," Journal of Political Economy, Vol. 113 (2), pp. 345-75.

Glaeser, Edward, and Joseph Gyourko, 2017, "The Economic Implications of Housing Supply," No. w23833. National Bureau of Economic Research.

Glaeser, Edward, and Albert Saiz, 2004, "The Rise of the Skilled City," FRB Philadelphia Working Paper No.04-2.

Hutton, Mercedes, 2018, “Japan's Hokkaido, the 'Aspen of Asia,' Offers Strong Investment Opportunities in a Growing Market," Mansion Global.

https:/www.mansionglobal.com/articles/japan-s-hokkaido-the-aspen-of-asia-offers-stronginvestment-opportunities-in-a-growing-market-112545

International Monetary Fund, 2017, “Asia: At Risk of Growing Old before Becoming Rich?" Chapter 2 in May 2017 Regional Economic Outlook for Asia and Pacific, International Monetary Fund, Washington DC.

International Monetary Fund, 2018, "Japan: 2018 Article IV Consultation - Staff Report," IMF Country Report 18/333, International Monetary Fund, Washington DC.

International Monetary Fund, 2020, "Japan: 2019 Article IV Consultation - Staff Report," IMF Country Report 20/39, International Monetary Fund, Washington DC.

Kobayashi, Masahiro, 2016, “The Housing Market and Housing Policies in Japan,” ADBI Working Paper 558. Tokyo: Asian Development Bank Institute. Available: http://www.adb.org/publications/housing-market-and-housing-policies-japan/

McGrattan, R. Ellen, Kazuaki Miyachi and Adrian Peralta-Alva, 2018, “On Financing Retirement, Health and Long-Term Care in Japan," IMF Working Paper 18/249, International Monetary Fund, Washington DC.

Nguyen, Anh Thi Ngoc, 2020, “Japan's Inbound Tourism Boom: Lessons for its PostCOVID-19 Revival," Working Paper 20/169, International Monetary Fund, Washington DC. 
Nishioka, Hachiro, Masato Shimizu, Yoshimi Chitose, Shiro Koike, and Hiroshi Kojima, 2010, "Recent Migration Trends in Japan Overview of the Results of the Sixth National Survey on Migration (2006)", The Japanese Journal of Population, Vol. 8, No.1.

OECD, 2019, “Adapting to Demographic Change," OECD publishing, Paris.

http://www.oecd.org/g20/summits/osaka/OECD-Ageing-and-Demographic-change-G20$\underline{\text { JPN.pdf }}$

Saita,Y, C. Shimizu, T. Watanabe, 2013, "Aging and Real Estate Prices: Evidence from Japanese and U.S. Regional Data," Tokyo Center for Economic Research (TCER), Paper No. E-68.

Shapiro, Jesse, 2006, "Smart Cities: Quality of Life, Productivity, and the Growth Effects of Human Capital," Review of Economics and Statistics, Vol. 88 (2), pp. 324-35.

Shirakawa, Masaaki, 2012, "Demographic Changes and Macroeconomic Performance: Japanese Experiences," Speech at the BOJ-IMES Conference, hosted by the Institute for Monetary and Economic Studies, Bank of Japan, Tokyo, May 30.

United Nations, 2017, "World Population Prospects," Department of Economic and Social Affairs, Population Division.

Westelius, Niklas and Yihan Liu, 2016, "The Impact of Demographics on Productivity and Inflation in Japan," IMF Working Paper 16/237, International Monetary Fund, Washington DC. 


\section{Annex A. Household Numbers and the Housing Market}

We conduct the empirical analysis in Section III. B, replacing prefecture-level population with the number of households.

First, in the long sample covering 1970 to 2015, an increase in the number of households has a significantly positive correlation with increasing housing prices, while such a relationship does not exist with a decrease in household numbers (Table 1). However, the positive correlation between an increase in household numbers and housing prices is merely due to the historical sample (1970-2000), where there was no prefecture that recorded a decline in the number of households. In the most recent sample, covering 2000 to 2015, a decline in the number of households is most significantly related to the change in housing prices - a positive coefficient implying that a decline in household numbers is related to a decline in housing prices.

\begin{tabular}{|c|c|c|c|c|c|c|c|c|c|}
\hline \multirow{3}{*}{$\begin{array}{l}\text { VARIABLES } \\
\text { HHLOSS }\end{array}$} & \multicolumn{9}{|c|}{ Dependent variable: $\% \Delta$ real land price } \\
\hline & \multicolumn{3}{|c|}{$1970-2015$} & \multicolumn{3}{|c|}{$1970-2000$} & \multicolumn{3}{|c|}{$2000-2015$} \\
\hline & $\begin{array}{c}5.961 \\
(4.446)\end{array}$ & $\begin{array}{c}12.44 \\
(7.504)\end{array}$ & $\begin{array}{l}15.77^{\star} \\
(8.005)\end{array}$ & - & - & - & $\begin{array}{c}24.01^{\star \star *} \\
(4.410)\end{array}$ & $\begin{array}{c}23.85^{\star \star \star \star} \\
(4.235)\end{array}$ & $\begin{array}{c}23.92^{\star \star \star \star} \\
(4.252)\end{array}$ \\
\hline HHGAIN & $\begin{array}{c}3.091^{* * *} \\
(0.783)\end{array}$ & $\begin{array}{l}1.818^{\star *} \\
(0.819)\end{array}$ & $\begin{array}{c}3.011^{* * *} \\
(1.097)\end{array}$ & $\begin{array}{l}7.004^{* \star \star} \\
(1.559)\end{array}$ & $\begin{array}{c}3.785 \\
(2.321)\end{array}$ & $\begin{array}{l}7.700^{* *} \\
(3.203)\end{array}$ & $\begin{array}{c}0.357 \\
(0.797)\end{array}$ & $\begin{array}{c}0.443 \\
(0.851)\end{array}$ & $\begin{array}{c}0.567 \\
(0.809)\end{array}$ \\
\hline$\Delta \ln$ OLDDEP & & $\begin{array}{c}-1.516^{* * * *} \\
(0.355)\end{array}$ & $\begin{array}{c}-1.721^{\star \star \star \star} \\
(0.391)\end{array}$ & & $\begin{array}{l}-3.047^{* *} \\
(1.438)\end{array}$ & $\begin{array}{l}-5.279^{*} \\
(2.641)\end{array}$ & & $\begin{array}{l}-0.177 \\
(0.298)\end{array}$ & $\begin{array}{l}-0.165 \\
(0.317)\end{array}$ \\
\hline$\Delta$ In Vacancy rate & & & $\begin{array}{l}-0.305^{\star} \\
(0.153)\end{array}$ & & & $\begin{array}{l}-0.425 \\
(0.268)\end{array}$ & & & $\begin{array}{l}0.0400 \\
(0.196)\end{array}$ \\
\hline Constant & $\begin{array}{l}-0.145^{\star *} \\
(0.0606)\end{array}$ & $\begin{array}{l}0.165^{*} \\
(0.0961)\end{array}$ & $\begin{array}{l}0.727^{\star \star *} \\
(0.0984)\end{array}$ & $\begin{array}{c}-0.427^{\star \star \star} \\
(0.116)\end{array}$ & $\begin{array}{c}0.244 \\
(0.356)\end{array}$ & $\begin{array}{l}0.938^{* *} \\
(0.460)\end{array}$ & $\begin{array}{c}-0.216^{\star * \star} \\
(0.0375)\end{array}$ & $\begin{array}{c}-0.188^{* * *} \\
(0.0495)\end{array}$ & $\begin{array}{l}-0.200^{\star \star *} \\
(0.0714)\end{array}$ \\
\hline Observations & 376 & 376 & 329 & 188 & 188 & 141 & 141 & 141 & 141 \\
\hline R-squared & 0.703 & 0.720 & 0.747 & 0.647 & 0.663 & 0.720 & 0.340 & 0.342 & 0.343 \\
\hline Number of code & 47 & 47 & 47 & 47 & 47 & 47 & 47 & 47 & 47 \\
\hline Fixed effects & $\mathrm{Y}$ & $\mathrm{Y}$ & $\mathrm{Y}$ & $\mathrm{Y}$ & $\mathrm{Y}$ & $\mathrm{Y}$ & $\mathrm{Y}$ & $\mathrm{Y}$ & $\mathrm{Y}$ \\
\hline Time effects & $\mathrm{Y}$ & $\mathrm{Y}$ & $\mathrm{Y}$ & $\mathrm{Y}$ & $\mathrm{Y}$ & $\mathrm{Y}$ & $\mathrm{Y}$ & $\mathrm{Y}$ & $\mathrm{Y}$ \\
\hline
\end{tabular}

The two regressions below assess the relationship between population dynamics and the number of households.

$$
\text { household growth }(\%)_{i, t}=\alpha_{i}+\alpha_{t}+\text { population growth }+\varepsilon_{i t}
$$

The results show that the number of households increased in proportion to population growth, but the correlation becomes weaker (as expected, especially after 2000 when population decline kicks in) (Table 2).

Treating population losses and gains separately, we run the following regression: 
household growth rate $(\%)_{i, t}=\alpha_{i}+\alpha_{t}+\beta P O P L_{O S S} S_{i, t-1}+\gamma P O P G A I N_{i, t-1}+\varepsilon_{i t}$

Results are reported in Table 3. Regarding population gain/loss and household numbers, the relationship has weakened in recent years (reported in the last column) as population losses do not affect household numbers and only population gains strongly increased household numbers. This result also suggests that the household number increases are strongly skewed by population and household dynamics in large cities.

Table 2. Number of Households and Population Growth

\begin{tabular}{lccc}
\hline VARIABLES & $\mathrm{HH}$ & $\mathrm{HH}$ & $\mathrm{HH}$ \\
\hline \multirow{3}{*}{ Population } & $0.750^{* * *}$ & $0.728^{* * *}$ & $0.419^{* * *}$ \\
& $(0.0402)$ & $(0.0423)$ & $(0.132)$ \\
Constant & $0.0123^{* * *}$ & $0.0125^{* * *}$ & $0.00846 * *$ \\
& $(0.000768)$ & $(0.000696)$ & $(0.000223)$
\end{tabular}

\begin{tabular}{|c|c|c|c|}
\hline Observations & 2,067 & 1,315 & 658 \\
\hline R-squared & 0.860 & 0.756 & 0.649 \\
\hline Number of code & 47 & 47 & 47 \\
\hline Fixed effects & $\mathrm{Y}$ & $\mathrm{Y}$ & $\mathrm{Y}$ \\
\hline Time effects & Y & Y & Y \\
\hline Time-averaging & 1970-2015 & $1970-2000$ & 2000-2015 \\
\hline
\end{tabular}

Table 3. Number of Households and Population Change

\begin{tabular}{lccc}
\hline VARIABLES & $\mathrm{HH}$ & $\mathrm{HH}$ & $\mathrm{HH}$ \\
\hline & & & \\
POPLOSS & $0.541^{* * *}$ & $0.477^{*}$ & 0.158 \\
& $(0.0947)$ & $(0.268)$ & $(0.109)$ \\
POPGAIN & $0.672^{* * *}$ & $0.627^{* * *}$ & $0.822^{* * *}$ \\
& $(0.0338)$ & $(0.0382)$ & $(0.105)$ \\
Constant & $0.0125^{* * *}$ & $0.0130^{* * *}$ & $0.00749^{* * *}$ \\
& $(0.000714)$ & $(0.000667)$ & $(0.000281)$ \\
& & & \\
Observations & 1,936 & 1,205 & 596 \\
R-squared & 0.829 & 0.677 & 0.662 \\
Number of code & 47 & 47 & 47 \\
Fixed effects & $\mathrm{Y}$ & $\mathrm{Y}$ & $\mathrm{Y}$ \\
Time effects & $\mathrm{Y}$ & $\mathrm{Y}$ & $\mathrm{Y}$ \\
Time-averaging & $1970-2015$ & $1970-2000$ & $2000-2015$ \\
\hline \multicolumn{4}{l}{ Robust standard errors in parentheses } \\
*** p<0.01, ** $\mathrm{p}<0.05, * \mathrm{p}<0.1$ & &
\end{tabular}




\section{Annex B. Development of Housing Market in Japan from 1982 to 2012}

\section{Bubble period (1982 to 1990):}

- Real estate prices across Japan rose by as much as six to seven times during the 1980 s asset bubble period. Low interest rates due to accommodative monetary policy by the Bank of Japan fueled high growth in the economy and fueled stock price increase. Japanese corporations, awash with cash, made speculative purchases of real estate and corporate assets all over the world.

- Following the Plaza Accord in 1985, the yen appreciated by about 50 percent from around $¥ 240$ /USD to about $¥ 120$ /USD in less than a year. In response, the Bank of Japan lowered interest rates from 5.5 percent to 2.5 percent in 1987 . This dramatic easing of monetary policy at a time of economic strength sparked an explosion of real estate transactions and high stock prices. Adding fuel to the fire, the government under Prime Minister Nakasone reduced corporate tax rates from 43.3 percent to 42 percent and slashed top marginal income tax rates from 70 percent to 40 percent, partly reflecting tensions over trade frictions against the United States. It was said at the time that the value of the Imperial Palace in Tokyo exceeded the value of all the real estate in California. Land in Ginza 4 Chome was reported to have traded at $¥ 90,000,000$ (US\$750,000 at the time) per square meter.

\section{Bubble burst:}

- In 1990, the Ministry of Finance put restrictions on the total loan volume of real estate lending (Soryo-kisei) which caused an immediate and dramatic drop in the availability of credit. Other government restrictions resulted in the need for buyers to seek approval from the local ward office for transactions of land size over 100 square meters. These restrictions brought the price rises to a grinding halt. The Bank of Japan also tightened interest rates to peak of 6 percent in 1990 .

- In December 1989, the Nikkei average reached its all-time high of 38,915. In the following nine months it crashed to below 20,000. Financial institutions were swamped with bad loans as asset prices tumbled. Land prices were slower to react but eventually started dropping and continued to slide downwards for the next ten years. By 1995, the Bank of Japan had dramatically reversed its monetary policy, slashing rates to a previously unthinkable 0.50 percent in an effort to stem the slide of the economy and asset prices.

3. Mini Bubble (2002 to 2008):

- The Bank of Japan cut rates further to 0.1 percent and began extremely aggressive monetary policy by introducing QE (Quantitative Easing) against the stagnating economy. Around this time, the J-REIT market started and the newly-listed investment trusts caused a flurry of activity in the property market. In the early years of $2000 \mathrm{~s}$, there were trillions of yen worth of securitized real estate transactions conducted, which led to a mini "fund boom" in real estate prices. These investment trusts focused their attention on assets in the 
major cities. As a result, prices in some parts of central Tokyo rose as much 70 to 100 percent compared to lows seen in 2002 but the overall market continued to languish.

\section{Mini Bubble burst:}

- By 2006, it seemed once again that a bubble was beginning so the Ministry of Finance moved again to restrict investment in real estate loans.

- The Great Financial Crisis. The global financial markets then took center stage as the U.S. sub-prime loan scandal erupted in 2007, culminating in the "Lehman shock" of 2008. Foreign investors disappeared from the Japanese real estate market as the securitized nonrecourse lending market ceased to exist.

- Real estate prices in Tokyo once again slumped but did not return to the lows of 2002. By 2010 prices managed to stabilize at levels around 50 percent above the previous lows. 


\section{Annex C. Japan Tax Policies Related to the Housing Market}

- Stamp tax: charged to register and transfer the title of the property.

- City planning tax: charged on the land and structures at $0.3 \%$ of the taxable base.

- $\quad$ Real estate acquisition tax: charged on land and structures at $4 \%$ of the taxable base.

- Consumption tax: payable on sale of a building (when purchased from a taxable person) but does not apply to sale of land.

- Income Tax Deduction for Mortgages: $1 \%$ of the outstanding balance of a mortgage is deducted from the amount of income tax.

- Property tax: charged on the land and structures at 1.4 percent of the taxable base. There is an exceptional treatment for small residential properties wherein the taxable base on the land is reduced to one sixth of the appraised value if there remains a residential structure on it (the background for this is to accelerate the high utilization of land by giving an incentive to home construction). This was cited as one of the causes of the high vacancy rate in Japan because, even after the property is not occupied and had better be demolished, the owner of the property had an incentive to leave the property as it is to enjoy a lower property tax rate. To remove such poor housing stock, new legislation was enacted in 2014 to accelerate the removal of such vacant houses.

- Assistance for the elderly: Elderly people usually have less physical competence than the working-age population, and housing units that accommodate such people must have several different structures in terms of accessibility and others. Business entities or persons who provide these types of facilities are granted a subsidy for the construction cost, accelerated depreciation for income tax, and reduction of property tax, among others. The JHF also extends mortgages for the construction or purchase of properties for such purposes.

Inheritance/Bequest tax: The inheritance tax burden in Japan is much heavier than in the United States and most developed economies. If one plans a bequest, it is preferable, from the standpoint of saving taxes, to hold real estate rather than financial wealth. This is because financial assets have been evaluated at market value and real estate has historically been evaluated below market value in the assessment for bequest taxes until the early 1990s. As a result, there is a strong tax incentive for Japanese households to hold real estate and take out housing loans, since the latter is tax deductible at market value if one is to carry out a bequest. Also, for residential real estate, there are huge tax deductions in general. Since there is a fairly solid consensus on strong bequest motives among Japanese, such a tax system explains why Japanese households prefer to hold owner-occupied houses rather than rent houses. It also helps to explain why the elderly in Japan retain houses and other real estate until their death. 